\title{
LA JURISDICCIÓN VOLUNTARIA Y LAS LEYES CIVILES AUTONÓMICAS'
}

\author{
Non-Contentious Proceedings \\ and Special or Provincial Civil Laws
}

\author{
Ma ÁNGELES PARRA LUCÁN \\ Universidad de Zaragoza \\ aparra@unizar.es
}

Cómo citar/Citation

Parra Lucán, M. A. (2016).

La jurisdicción voluntaria y las leyes civiles autonómicas.

Derecho Privado y Constitución, 30, 127-175.

doi: http://dx.doi.org/10.18042/cepc/dpc.30.03

(Recepción: 29/06/2016; aceptación después de la revisión: 19/07/2016; publicación: 17/1 1/2016)

\section{Resumen}

Este trabajo analiza las relaciones entre la Ley de la Jurisdicción Voluntaria (LJV) aprobada por el legislador estatal en el año 2015 y las leyes civiles autonómicas, que contienen abundantes supuestos de jurisdicción voluntaria. Se pone de relieve cómo el desarrollo legislativo autonómico producido después de la Constitución de 1978 en materia de derecho civil provoca desajustes y disfunciones, en particular por la diferente atribución de la competencia para tramitar los expedientes de jurisdicción voluntaria a cuerpos de funcionarios nacionales (jueces, letrados de la Administración

1 Este trabajo forma parte de las actividades del proyecto $\mathrm{I}+\mathrm{D}+\mathrm{i}$ «Análisis de las fronteras de la autonomía privada en el Derecho civil» (DER2014-52252), financiado por el Ministerio de Economía y Competitividad y del grupo de investigación consolidado Autonomía de la Voluntad en el Derecho Privado (AUDEPRIV S110, Gobierno de Aragón y Unión Europea-Fondo Social Europeo). 
de Justicia, notarios), lo que no siempre está justificado y contradice las opciones políticas adoptadas por el legislador estatal al aprobar la LJV.

\section{Palabras clave}

Jurisdicción voluntaria; derechos civiles forales; derechos civiles especiales.

\section{Abstract}

This piece of work analyzes the relationship between the Non-contentious proceedings Act passed by the national parliament in 2015 and the civil laws of the Autonomous Communities (special or provincial civil laws), which contain a large amount of Non-contentious proceedings. It highlights how the autonomic legislative development in Civil law that has been taking place since the passing of the 1978 Constitution has created imbalances and malfunctions, particularly because of the different assignation of competences to deal with Non-contentious proceedings to public servants (judges, court clerks, notaries and registrars). This different assignation is not always justified and contradicts the political options adopted by the national legislator when passing the Non-contentious proceedings Act.

\section{Keywords}

Non-contentious proceedings; special civil laws; provincial civil laws. 


\section{SUMARIO}

I. AUTONOMÍA PRIVADA, JURISDICCIÓN VOLUNTARIA Y DERECHOS CIVILES. II. SUPUESTOS DE JURISDICCIÓN VOLUNTARIA EN LAS LEYES AUTONÓMICAS. III. UNA SOLA LEY DE JURISDICCIÓN VOLUNTARIA Y PLURALIDAD DE DERECHOS CIVILES: 1. Planteamiento; 2. La disposición adicional primera de la LJV. IV. CONCURRENCIA DE MATERIAS Y COMPETENCIAS LEGISLATIVAS: 1. Derecho procesal; 2. Derecho civil; 3. Concurrencia de competencias. Identificación de algunos problemas; 4 . Ordenación de los registros e instrumentos públicos; 5 . Distribución de funciones entre jueces y letrados de la Administración de Justicia. V. JURISDICCIÓN VOLUNTARIA Y PLURALIDAD DE DERECHOS CIVILES: PANORAMA LEGISLATIVO Y PERSPECTIVAS DE FUTURO. VI. BIBLIOGRAFÍA.

\section{AUTONOMÍA PRIVADA, JURISDICCIÓN VOLUNTARIA Y DERECHOS CIVILES}

De entre todas las consideraciones que pueden hacerse en torno a la jurisdicción voluntaria, interesa ahora señalar el carácter adjetivo que le reconoce la exposición de motivos de la Ley 15/2015, de 2 de julio, de la Jurisdicción Voluntaria, en la que se afirma cómo «al operar como cauce de actuación y de efectividad de determinados derechos regulados en el Código Civil, en el Código de Comercio y en la legislación especial de Derecho privado, no es difícil deducir el carácter adjetivo o auxiliar de la jurisdicción voluntaria».

Añade la exposición de motivos de la citada ley que: «La jurisdicción voluntaria se vincula con la existencia de supuestos en que se justifica el establecimiento de limitaciones a la autonomía de la voluntad en el ámbito del Derecho privado, que impiden obtener un determinado efecto jurídico cuando la trascendencia de la materia afectada, la naturaleza del interés en juego o su incidencia en el estatuto de los interesados o afectados, así lo justifiquen. O también, con la imposibilidad de contar con el concurso de las voluntades individuales precisas para constituir o dar eficacia a un determinado derecho».

La primera reflexión que suscita este razonamiento es que, precisamente por su carácter adjetivo o auxiliar, como cauce para la efectividad de los 
derechos regulados en el derecho civil material, la regulación de la jurisdicción voluntaria debe adecuarse a la regulación sustantiva vigente y, puesto que la regulación civil estatal no es la única existente en España, es preciso comprobar en qué medida incide la regulación contenida en la Ley de la jurisdicción voluntaria en la pluralidad de derechos civiles españoles.

A esta reflexión debe añadirse otra que también sugieren los párrafos transcritos de la exposición de motivos de la Ley. La idea de que la jurisdicción voluntaria se justifica en las limitaciones a la autonomía de la voluntad, responde al presupuesto de que en algunos sectores del derecho privado, y más en particular, del derecho civil, la eficacia de la autonomía de la voluntad viene configurada legalmente de modo que para que se produzcan algunos efectos, para la plena validez del acto o negocio, para que puedan ejercitarse ciertos derechos o cargos o queden determinadas algunas relaciones jurídicas, es precisa la intervención de una autoridad.

Explicada de esta forma la jurisdicción voluntaria, las limitaciones a la autonomía de la voluntad y la exigencia de intervención de un funcionario para la eficacia de determinados actos o declaraciones privadas no pueden venir impuestas en todas las hipótesis por el legislador estatal, sino en cada caso por el legislador que sea competente para regular la materia, de acuerdo con el ámbito competencial diseñado por la Constitución y por los estatutos de autonomía. En definitiva, que son el legislador estatal o los autonómicos quienes, en la esfera de su competencia sobre el derecho civil, están legitimados para determinar si se limita o no la autonomía de la voluntad y si es precisa la intervención de una autoridad o funcionario para que un acto sea válido, oponible a terceros, o para acceder a un cargo, para reconocer legitimación a una persona para realizar cierto acto o negocio, etc. Puede comprenderse fácilmente que, si el contenido de los supuestos de jurisdicción voluntaria va parejo a la regulación de derecho civil, el desarrollo producido en la legislación civil autonómica ha dado lugar a un incremento más que notable de las hipótesis «autonómicas» o «forales» de jurisdicción voluntaria.

Resulta difícil evitar, sin embargo, que el legislador estatal, al establecer los cauces y procedimientos en los que es necesaria la intervención de un funcionario público, tenga en cuenta exclusivamente el derecho civil estatal, sobre el que tiene competencia. Ello ha provocado desajustes entre la Ley de la jurisdicción voluntaria y los derechos civiles autonómicos: en ocasiones porque, al regular un expediente, la Ley estatal de jurisdicción voluntaria da por supuesto que es necesaria la intervención de una autoridad o funcionario en hipótesis en las que, conforme al derecho autonómico aplicable, no es precisa; a veces, por el contrario, porque la Ley de la jurisdicción voluntaria no establece un procedimiento para hipótesis que son de jurisdicción volun- 
taria conforme al derecho civil autonómico, pero que no están contempladas en el Código Civil.

La dificultad en este ámbito se produce porque concurren normas de diferentes ordenamientos jurídicos y una pluralidad de competencias legislativas. En los distintos supuestos considerados como jurisdicción voluntaria se atribuye una tarea a funcionarios de cuerpos nacionales, lo que suscita la duda, no solo de la oportunidad de soluciones diferentes en función del derecho civil aplicable, sino sobre todo de la cobertura constitucional para dictar semejantes normas.

\section{SUPUESTOS DE JURISDICCIÓN VOLUNTARIA EN LAS LEYES AUTONÓMICAS}

En las leyes autonómicas de derecho civil hay abundantes hipótesis de jurisdicción voluntaria. Las había en las Compilaciones, que fueron aprobadas como leyes estatales con anterioridad a la Constitución de 1978. Después de la Constitución, los legisladores autonómicos han introducido nuevos supuestos, de forma paralela al ejercicio creciente de la competencia legislativa sobre derecho civil. En el momento actual pueden identificarse diferentes grupos de casos.

En primer lugar, en ocasiones, el legislador autonómico se remite expresamente a un procedimiento de jurisdicción voluntaria. Cuando utiliza esta expresión, la ley autonómica siempre encomienda la competencia al juez, de forma coherente con la legislación anterior contenida en la vieja Ley de enjuiciamiento civil de 1881, vigente en materia de jurisdicción voluntaria hasta su derogación por la LJV. Tras la promulgación de esta última, es preciso valorar si se requiere que esa función deba ser atribuida en determinados casos al letrado de la Administración de Justicia, de manera coherente con las nuevas competencias que se han atribuido legalmente a este cuerpo de funcionarios ${ }^{2}$.

Algunos de estos asuntos que las leyes autonómicas califican expresamente como jurisdicción voluntaria son autorizaciones, legitimaciones, nombramientos de cargos, atribución de funciones... ${ }^{3}$

2 Sobre las nuevas funciones que se atribuyen a este cuerpo de funcionarios, en especial en materia de jurisdicción voluntaria, vid. el art. 456.6.b) de la Ley Orgánica del Poder Judicial, redactado por la Ley Orgánica 7/2015, de 21 de julio.

3 Para calibrar el alcance y la heterogeneidad de los supuestos, merece la pena recordar algunos de ellos: 
Otros supuestos, en cambio, se ocupan de «pequeños» conflictos ya abiertos, para los que el legislador autonómico opta por buscar una solución más ágil

- Art. 225-3 del Código civil de Cataluña. Funciones del guardador de hecho: «2. En la guarda de hecho de personas que estén en potestad parental o en tutela, la autoridad judicial puede conferir al guardador, si lo solicitan aquellas personas, las funciones tutelares, $[\ldots]$ en un procedimiento de jurisdicción voluntaria, con la audiencia de las personas titulares de la potestad o tutela si es posible».

- Art. 226-1 del Código civil de Cataluña. Nombramiento de asistente: «1. La persona mayor de edad que lo necesite para cuidar de ella misma o de sus bienes, debido a la disminución no incapacitante de sus facultades físicas o psíquicas, puede solicitar a la autoridad judicial el nombramiento de un asistente, de acuerdo con lo establecido por el presente capítulo, por el procedimiento de jurisdicción voluntaria».

- Art. 426-24 del Código civil de Cataluña. Fideicomisarios no nacidos ni concebidos: «2. El fideicomitente, al ordenar el fideicomiso, o en testamento o codicilo posteriores, puede nombrar a uno o varios curadores y a sus suplentes. Si no lo hace o si faltan los designados, su nombramiento corresponde a la autoridad judicial, de acuerdo con el procedimiento de jurisdicción voluntaria».

- Art. 426-40 del Código civil de Cataluña. Disposición de bienes libres de fideicomiso con autorización judicial: «3. La autorización judicial tiene lugar por el procedimiento de jurisdicción voluntaria, previa notificación a los fideicomisarios y al curador, si existen, sin necesidad de la subasta».

- Art. 461-23 del Código civil de Cataluña. Beneficio de separación de patrimonios: «1. Los acreedores por deudas del causante y los legatarios pueden solicitar al juez competente, en procedimiento de jurisdicción voluntaria [...]. También pueden solicitarlo los acreedores del heredero, para salvaguardar su derecho ante los acreedores por deudas del causante. 2. Una vez tomado el inventario de la herencia, el juez, con la motivación adecuada, concede el beneficio de separación de patrimonios y adopta, si procede, las medidas necesarias para hacerlo efectivo".

- La Exposición de Motivos del Código de Derecho Foral de Aragón aclara que la decisión de la Junta de Parientes, ya sea positiva o negativa, impide someter el mismo asunto a otro órgano de decisión (art. 178.2) -en particular, al juez en funciones de jurisdicción voluntaria- y se recuerda que en la norma se precisan los casos en los que el transcurso de un mes sin haber obtenido acuerdo permite acudir a otra vía (art. 181).

- Art. 175 del Código Foral. Constitución judicial y funcionamiento de esta Junta: «1. Cuando en documento público se haya configurado como órgano permanente, así como cuando no se quiera o pueda constituir bajo fe notarial, el juez del domicilio de la persona o familia de cuya Junta se trate ordenará, a instancia de parte interesada, su constitución en expediente de jurisdicción voluntaria».

- Ley 233 de la Compilación de Navarra. Enajenación y gravamen: «El fiduciario podrá enajenar y gravar los bienes como libres en los casos y modos siguientes: [...] con autorización del juez competente, que la concederá sólo en casos de necesidad o utilidad evidente, en acto de jurisdicción voluntaria y adoptando las medidas oportunas para asegurar la subrogación». 
en la jurisdicción voluntaria. El fundamento es el mismo que inspira al legislador estatal cuando ordena tramitar como jurisdicción voluntaria discrepancias que considera de menor intensidad: se trata, en definitiva, de hipótesis en las que se valora que, en atención a la urgencia de la decisión o a la falta de complejidad del asunto, es preferible que el interés debatido se resuelva de manera sencilla y rápida ${ }^{4}$. Los riesgos que puede conllevar la tramitación de asuntos con contienda como un expediente de jurisdicción voluntaria se ven ahora reducidos, desde el punto de vista del procedimiento, con la admisión de la oposición de cualquiera de los interesados (art. 17.3 segundo párrafo de la LJV) y con el sistema de recursos que se introduce en la nueva Ley (art. 20 de la LJV).

En segundo lugar, en otras ocasiones la norma autonómica no utiliza la expresión "jurisdicción voluntaria», pero la función que contempla es equivalente a lo que se venía considerando como tal con anterioridad y se recoge ahora en la vigente LJV.

Así sucede cuando la norma contiene una llamada al juez para que intervenga en asuntos en los que no existe un conflicto. Son los casos en los que la norma autonómica exige una autorización para la celebración de actos de disposición, confección de un inventario, nombramiento de un cargo tutelar en sentido amplio, adveración de un testamento, garantía de que los bienes del causante no se confunden con los del heredero para que puedan cobrar del patrimonio de su deudor, etc. Aunque las normas no afirmen de forma expresa que se trata de jurisdicción voluntaria, se vienen tramitando así, a veces incluso sin que exista un procedimiento específico 5 .

4 Es el caso, por ejemplo, de los siguientes preceptos autonómicos:

- Art. 428-5 del Código civil de Cataluña. Modo imposible o ilícito: «2. No se considera que el modo sea de cumplimiento imposible si puede alcanzarse la misma finalidad que perseguía el testador aunque en un grado inferior o en términos diferentes a los que había ordenado. En este caso, a instancia de la persona gravada con el modo o de cualquiera de las personas legitimadas para pedir su cumplimiento, la autoridad judicial competente puede decretar, en procedimiento de jurisdicción voluntaria, la conmutación o la conversión del modo».

- Art. 451-12 del Código civil de Cataluña. Calidad de los bienes: «1. Si las personas a que se refiere el art. 451-11 optan por el pago en bienes y el legitimario no se conforma con los que se le pretendan adjudicar, este puede recorrer a la autoridad judicial competente, que debe decidir con equidad y por el procedimiento de jurisdicción voluntaria».

5 Además de los llamamientos a la autoridad judicial para que autorice actos de disposición por parte de los representantes de los menores o personas con capacidad modificada judicialmente, de forma análoga a lo que establece el Código Civil, hay otros 
La llamada, en ocasiones, no es al juez, sino a un «órgano» familiar, al que se encomiendan funciones equivalentes a las que desempeña el juez en la jurisdicción voluntaria. Es el caso del Consejo de Parientes del derecho catalán $^{6}$, los Parientes Mayores navarros ${ }^{7}$ o, de forma mucho más amplia, la Junta de Parientes aragonesa ${ }^{8}$.

supuestos específicos de los derechos civiles forales o especiales en los que se requiere la intervención del juez. Entre otros, por ejemplo, los siguientes:

- Ley 319 de la Compilación de Navarra. Beneficio de separación: "Los acreedores hereditarios, dentro del plazo de seis meses, a contar de la fecha del fallecimiento del causante, podrán solicitar del juez la formación del inventario y la separación de los bienes de la herencia [...]».

- Art. 23 de la Ley de Derecho civil del País Vasco 2015. Testamento en peligro de muerte o "hilburuko»: «1. El que, por enfermedad grave u otra causa, se halle en peligro inminente de muerte, podrá otorgar testamento ante tres testigos idóneos sin intervención de notario [...]. Adverado judicialmente un testamento se procederá a su protocolización notarial». En relación con este supuesto, hay que llamar la atención sobre el dato de que el mismo día 3 de julio de 2015, fecha en que se publicaba en el BOPV esta Ley de Derecho Civil, el BOE publicaba la LJV, que modifica el art. 704 del Código Civil, de modo que, para el testamento en peligro de muerte (que es la naturaleza del testamento contemplado en el art. 23 de la ley vasca), se remite a la protocolización conforme a la legislación notarial.

- Art. 21 de la Ley de Derecho Civil del País Vasco. Gastos de la sucesión y beneficio de separación: " [...] A los efectos de la responsabilidad de los herederos se establece el beneficio de separación que los acreedores hereditarios, dentro del plazo de seis meses, a contar de la fecha del fallecimiento del causante, podrán solicitar del juez la formación de inventario y la separación de los bienes de la herencia [...] $E l$ juez, a petición de los interesados, señalará plazo para la formación de inventario y decretará las anotaciones y embargos preventivos, notificaciones y demás medidas de aseguramiento".

- Art. 143 de la Ley de Derecho Civil del País Vasco 2015: «Aceptación de herencias por los sucesores a instancia del cónyuge viudo. El cónyuge viudo, cuando el matrimonio se haya disuelto con hijos o descendientes, podrá instar judicialmente a los sucesores del fallecido a que acepten cualquier herencia en que éste estuviera interesado. Transcurrido el plazo señalado por el juez, que no excederá de treinta días, sin que manifiesten su voluntad de aceptar la herencia, o cuando repudien la misma, podrá dicho cónyuge aceptarla a beneficio de inventario".

6 Vid. art. 236-30 del Código Civil de Cataluña. Autorizaciones alternativas (en materia de administración y disposición de bienes por los progenitores o por el administrador): «Puede sustituirse la autorización judicial por el consentimiento del acto, manifestado en escritura pública [...] b) De los dos parientes más próximos del hijo, en la forma establecida por el art. 424-6.1.a)» (dos parientes consanguíneos, uno de 
Finalmente, los derechos civiles autonómicos atribuyen funciones al notario, por ejemplo, para que confeccione un inventario como presupuesto para poder acceder a un cargo o para disfrutar de derechos de usufructo, etc. A veces, la tarea que se encomienda al notario lo es de forma alternativa a la que se asigna al juez, pero en otras ocasiones se encarga al notario en exclusiva?.

En los derechos autonómicos, por lo demás, encontramos algunos casos de llamadas al notario en las que se le encomienda alguna función específica dirigida a facilitar el otorgamiento de actos de disposición en casos en los que la acreditación rigurosa de los presupuestos legales para realizarlos retrasaría

cada línea de progenitores, con el vínculo de parentesco más próximo con los hijos o los descendientes; dentro de cada línea tiene preferencia el de más edad).

7 La Compilación de Navarra contiene algunos llamamientos a este órgano: ley 63, para resolver desacuerdos entre los padres, si ambos están de acuerdo en someter la decisión a los parientes; ley 66, asistencia de los parientes para complementar la capacidad del menor emancipado, o para enajenar bienes de cónyuges menores (ley 86); para apreciar si hay convivencia entre los donantes y los donatarios en el caso de la sociedad continuada (ley 97); para decidir algunos conflictos en los casos de disolución de las comunidades familiares (ley 128), resolución de conflictos en caso de acogimiento a la casa y de las dotaciones (leyes 132 y 134).

8 En el derecho aragonés son abundantes las llamadas a la Junta de Parientes, y con funciones diferentes, no solo en el derecho de la persona, también en familia y en sucesiones. Desde suplir la capacidad de los menores, como alternativa a los titulares de la autoridad familiar o del tutor o del juez, a autorizar actos de disposición (arts. 15 y 16 del Código Foral) o emitir un juicio para justificar la necesidad de un acto de disposición de bienes comunes por un solo cónyuge cuando se trata de satisfacer necesidades familiares, será suficiente la declaración, en ese sentido, de la Junta de $\mathrm{Pa}$ rientes del otro cónyuge (art. 230 del Código Foral), o autorizar al fiduciario para que realice actos de enajenación de inmuebles u otros bienes de especial valor (art. 454 del Código Foral). También se le atribuye la competencia de resolver pequeños conflictos familiares, siempre que los interesados estén de acuerdo en ello. Es interesante señalar que la actuación de este órgano familiar, cuando no es judicial (art. 175 del Código foral) se hace bajo fe notarial (art. 174 del Código Foral), lo que advierte de la exigencia formal con que el legislador quiere controlar su actuación.

9 Así, por ejemplo, no se adquiere el usufructo de fidelidad si no se confecciona un inventario notarial de los bienes (ley 257 de la Compilación de Navarra). En Aragón, el viudo, en los casos en que está obligado a confeccionar inventario, puede hacerlo judicial o extrajudicialmente, pero en tal caso en escritura pública (art. 286 del Código Foral). También en Aragón, en caso de fiducia, el administrador debe formalizar en escritura pública un inventario de todos los bienes y deudas de la herencia (art. 450 del Código Foral) y el tutor puede confeccionar inventario notarial o judicialmente (art. 141 del Código Foral). 
y dificultaría su celebración ${ }^{10}$. La intervención notarial, en las circunstancias descritas por estas normas, confiere legitimación con apoyo en la constatación de una situación de notoriedad. Es evidente que, por las consecuencias que pueden derivarse para terceros, será el notario quien deba valorar la oportunidad de otorgar el acta, pues puede incurrir en responsabilidad civil.

La comparación de las hipótesis analizadas que pueden calificarse como de jurisdicción voluntaria en los derechos civiles autonómicos con las que aparecen en el Código Civil muestra que no existe identidad en los asuntos de jurisdicción voluntaria.

Ello sucede, en primer lugar, porque hay algunos supuestos que no tienen equivalente en el Código Civil, en particular cuando se trata de instituciones propias del derecho autonómico que no existen en el derecho estatal (autoridad familiar de personas diferentes de los padres, usufructos legales universales del viudo, etc.) o que, incluso, están prohibidas en el mismo (testamento por comisario y fiducias sucesorias).

En ocasiones, para supuestos de jurisdicción voluntaria propios del derecho autonómico que no tienen equivalente en la ley estatal, ni cauce específico en la LJV porque se refieren a instituciones propias del derecho foral o especial, la legislación autonómica regula ciertos aspectos del procedimiento que debe seguirse. En general, sin embargo, y a falta de la regulación de un procedimiento específico, en la práctica se han venido aplicando con normalidad, a partir de los escritos de solicitud de los particulares y de las resoluciones judiciales, las reglas generales de la jurisdicción voluntaria — con las dificultades que derivaban de la práctica inexistencia de ese régimen general bajo la vigencia de la vieja ley_ o, por analogía, reglas de la jurisdicción voluntaria establecidas para otros supuestos análogos ${ }^{11}$.

10 Así sucede, por ejemplo, en los siguientes casos:

— Art. 231 del Código Foral de Aragón. Ejercicio de profesión o negocio: «1. Cada cónyuge estará legitimado para realizar los actos de administración o disposición incluidos en el tráfico habitual de su profesión o negocio. 2. Para probar en el tráfico que un acto está incluido en el giro habitual del que lo realiza, bastará que así resulte de la aseveración del notario de que le consta por notoriedad».

- Art. 47 de la Ley 2/2006, de 14 de junio, de Derecho Civil de Galicia: «La situación de ausencia efectiva del domicilio habitual podrá acreditarse mediante acta de notoriedad tramitada por notario hábil, en la cual se hará constar la persona a la que corresponde la representación y defensa de los intereses del ausente».

11 Este dato de lo que sucedía con anterioridad a la vigente LJV es relevante. Sirve para matizar el razonamiento que a priori pudiera defenderse en el sentido de que la desaparición de un procedimiento de la LJV — en particular, cuando se desjudicializa el expediente y se atribuye al notario— implica necesariamente, por esta sola razón, la «desaparición» del 
En segundo lugar, ocurre por el contrario que en el derecho estatal se tramitan como jurisdicción voluntaria asuntos que no son considerados como tales en todos los derechos civiles autonómicos ${ }^{12}$.

Finalmente, se observa también que, para ciertos expedientes de jurisdicción voluntaria equivalentes como categoría en el derecho estatal y los autonómicos, no hay coincidencia en la delimitación de los supuestos o en el señalamiento del órgano al que se llama para intervenir o en el efecto que se anuda a la tramitación del expediente o a su falta de tramitación.

Con carácter general, se advierte que las distintas normas materiales (estatales o autonómicas) incorporan soluciones diferentes en las que se mezclan aspectos sustantivos con otros de "procedimiento", judicial o no. Sucede en muchas ocasiones, pero si hay un supuesto en el que se aprecia con especial claridad la absoluta disparidad de tratamiento del mismo problema es el de la responsabilidad de los herederos por las deudas de la herencia y cuándo se produce el efecto del «beneficio de inventario».

En Aragón (arts. 349 y 355 del Código Foral) y Navarra (leyes 315 y 318 de la Compilación), la responsabilidad del heredero es intra vires, cualquiera que sea la forma de aceptación, incluso la tácita, y se haga o no inventario. En Cataluña, en cambio, los efectos legales del beneficio de inventario se producen si se formaliza el inventario de la herencia ante notario o por escrito

propio supuesto de jurisdicción voluntaria en las comunidades autónomas. A estos efectos, hay que recordar que la LJV solo regula los expedientes que se tramitan ante los órganos jurisdiccionales (art. 1.1) y no se ocupa de aquellos expedientes para los que, en derecho estatal (Código Civil), no es competente el juez. Contra el argumento que podría defenderse sin examinar el asunto, cabe advertir que también ahora, en su caso, cuando sea necesario, en el ámbito autonómico se podrá construir un procedimiento con apoyo en las reglas generales de la LJV o por analogía con otros expedientes. Es el caso, por ejemplo, de la Junta de Parientes en Aragón. González Poveda destacaba la falta de regulación del procedimiento en la Compilación para la constitución de la Junta y señalaba como solución adecuada la aplicación analógica de las normas de constitución de la tutela (González Poveda, 1997: 794). En la actualidad, el vigente art. 175 del Código foral se remite también al expediente de jurisdicción voluntaria y puede continuar aplicándose el mismo criterio.

12 Así, en los arts. 1001 del Código Civil y 93.2.c. de la LJV (también en el art. 353 del Código Foral aragonés) se contempla la llamada «aceptación de la herencia por los acreedores» en caso de que el llamado a una herencia renuncie a la misma en perjuicio de aquellos: los acreedores del llamado pueden pedir al juez que les autorice a aceptar la herencia en su beneficio y se tramita como expediente de jurisdicción voluntaria. La solución del art. 461-7 del Código Civil de Cataluña es otra: la renuncia, sencillamente, no es oponible a los acreedores del llamado, y pueden cobrar los créditos anteriores a la repudiación sobre los bienes de la herencia repudiada. 
dirigido al juez competente, pero también si el inventario formalizado por el heredero en documento privado se presenta a la administración pública competente para la liquidación de los impuestos relativos a la sucesión (art. 461-15 del Código Civil de Cataluña).

Con anterioridad a la LJV, en el Código Civil el beneficio de inventario requería una declaración «ante notario o por escrito al juez» (art. 1011). Pues bien, la LJV ha modificado este art. 1011, de modo que la declaración de beneficio de inventario ha de hacerse, después de la vigencia de la nueva ley, ante notario; además, se ha introducido una regulación de la confección del inventario en los arts. 67 y 68 de la Ley del Notariado.

Me parece indudable que las reformas del Código Civil y de la Ley del Notariado no han cambiado el régimen de la responsabilidad del heredero ni en Aragón ni en Navarra ni en Cataluña. Otra cosa es que, en una sucesión regida por las normas forales o especiales de estas comunidades autónomas, si se confecciona un inventario notarial, el notario deba adaptar su actuación a los preceptos de la Ley del Notariado.

Con este ejemplo quiero poner de relieve que las diferencias entre los distintos derechos civiles españoles existían ya antes de la LJV y que, hasta ese momento, los diferentes funcionarios llamados a intervenir y los operadores jurídicos utilizaban con normalidad la ley aplicable en cada caso con independencia de que fuera una ley estatal o una norma de derecho civil foral o especial dictada por un legislador autonómico. En buena medida porque, de esta forma, en última instancia, por si hiciera falta recordarlo, se da cumplimiento al mandato de una ley estatal, la que determina la ley aplicable en cada momento, contenida en el Código Civil, y cuya competencia corresponde en exclusiva al Estado (art. 149.1.8 ${ }^{\mathrm{a}}$, de la Constitución).

La promulgación de la LJV contribuye a que se cuestione el alcance de la competencia legislativa sobre el derecho civil de las comunidades autónomas: mueve a repensar las relaciones entre el derecho estatal y el autonómico, sobre todo cuando la modificación del derecho estatal tiene lugar en un ámbito en el que la regulación autonómica venía siendo coincidente con la estatal con anterioridad a la reforma y, como consecuencia de ella, ha dejado de serlo.

\section{UNA SOLA LEY DE JURISDICCIÓN VOLUNTARIA Y PLURALIDAD DE DERECHOS CIVILES}

\section{PLANTEAMIENTO}

Hay que llamar la atención sobre el contraste entre la pluralidad de derechos civiles españoles (que son competencia de los correspondientes parla- 
mentos autonómicos) y la existencia de una única LJV, aprobada por las Cortes Generales y que, a priori, se presenta como una ley de aplicación general y uniforme en todo el territorio español.

La fuente de los supuestos de jurisdicción voluntaria es la ley: es el legislador el que decide cuándo es precisa la intervención de un funcionario para aprobar/autorizar/homologar un acto, para que sea válido o produzca efectos, o para suplir consentimientos, proceder a nombramientos o dar posesión de algunos cargos de derecho privado, aceptar excusas o renuncias, prorrogar plazo para el cumplimiento de un encargo, confeccionar inventarios, etc.

Siendo esto así, puesto que hay, no solo pluralidad de derechos civiles sino, sobre todo, pluralidad de legisladores con competencia sobre el derecho civil, el resultado es que hay pluralidad de fuentes y pluralidad de legisladores para establecer hipótesis de jurisdicción voluntaria. En consecuencia, los casos de jurisdicción voluntaria no solo los encontramos en el Código Civil y en el derecho civil estatal, sino en cualquiera de los derechos civiles españoles vigentes. Esto, como he advertido, ya sucedía antes de la LJV. ¿Qué cambia entonces con la promulgación de dicha ley? Sencillamente que, al ser nueva, aprobada por el Estado, que introduce cambios en la regulación de la jurisdicción voluntaria, es preciso clarificar su incidencia en los supuestos que contienen las normas autonómicas.

El legislador estatal, que aprueba la LJV, por lo que ahora interesa, modifica al mismo tiempo el Código Civil, la Ley de Enjuiciamiento Civil y la Ley del Notariado, pero carece de competencia para modificar los derechos civiles autonómicos en los que se contemplan supuestos de jurisdicción voluntaria. Ello obliga a conciliar ambos conjuntos normativos, teniendo en cuenta la naturaleza de las normas y el ámbito competencial en cuyo marco encuentran cobertura.

En general, las reformas de la LJV han supuesto una desjudicialización de la jurisdicción voluntaria, bien para confiar al notario funciones que venían siendo atribuidas a la competencia del juez, bien para adjudicárselas al letrado de la Administración de Justicia. Se trata de opciones de política legislativa importantes, que afectan a las funciones atribuidas a cuerpos de funcionarios de ámbito nacional. La dificultad, sin duda, radica en determinar la repercusión de estas modificaciones operadas por la LJV en los derechos autonómicos. En particular, cabe preguntarse si son de aplicación automática en todo el territorio nacional, sin necesidad de reforma o si, por el contrario, es precisa una reforma del legislador autonómico que las incorpore e, incluso, si está obligado a hacerlo. 


\section{LA DISPOSICIÓN ADICIONAL PRIMERA DE LA LJV}

Consciente de la existencia de una pluralidad de derechos civiles, el legislador estatal introdujo en la LJV una disposición que tiene en cuenta este fenómeno. Se trata de la disposición adicional primera.3 de la LJV, en la que se ordena que «las referencias realizadas en esta Ley al Código Civil o a la legislación civil se entiendan realizadas también a las leyes civiles forales o especiales allí donde existan». La norma, aparentemente muy sencilla, resulta, sin embargo, insuficiente y, en ocasiones, imposible de aplicar.

La previsión legal tiene sentido cuando concurren dos circunstancias: a) que la norma contenida en la LJV pueda ser calificada como procesal, porque establece un procedimiento para una categoría de casos de jurisdicción voluntaria, y b) que esa misma categoría esté contemplada también en la norma civil autonómica ${ }^{13}$.

En cambio, la norma contenida en la disposición adicional primera.3 de la LJV es inútil cuando se trata de hipótesis de jurisdicción voluntaria previstas en el Código Civil, pero que no tienen equivalente en la legislación de la comunidad autónoma. Algunos ejemplos de esto ya han ido saliendo con anterioridad. Además, hay supuestos en la LJV que son absolutamente coherentes con la regulación del Código Civil, pero no guardan ninguna relación con el régimen previsto en algunos derechos civiles autonómicos ${ }^{14}$.

La insuficiencia de la disposición adicional primera de la LJV que acabo de denunciar no hubiera podido superarse mediante una modificación por el

13 Así, por ejemplo, no existe ninguna dificultad en entender que son aplicables las normas de procedimiento de los arts. 85 a 89 de la LJV a los supuestos de divergencias entre los padres (art. 74.2 del Código Foral de Aragón), nombramiento de un administrador de los bienes cuando los padres estén excluidos (art. 9.2), medidas de protección de menores y personas con capacidad modificada judicial (art. 10, incluidas las autorizaciones de los arts. 20 y 24). Hay preceptos equivalentes en otros derechos civiles autonómicos.

14 Esto es lo que sucede, por ejemplo, con lo dispuesto en el art. 100 de la LJV acerca de la autorización judicial al usufructuario para reclamar créditos vencidos que formen parte del usufructo, que concuerda con lo dispuesto en el art. 507 del Código Civil. Sin embargo, para el usufructo del viudo aragonés el régimen es diferente (arts. 285, 287, 299 del Código Foral). Y, en general, para el derecho de usufructo, el derecho catalán contiene normas propias alejadas del derecho civil estatal (arts. 561-22, 33 y 34-3 de su Código Civil). 
legislador estatal de todas las normas anteriores en las que se contemple un asunto de jurisdicción voluntaria, porque el legislador estatal carece de competencia para modificar las normas autonómicas ${ }^{15}$.

En realidad, para poder determinar con corrección las relaciones entre las normas de la LJV y las normas autonómicas de derecho civil, es preciso partir del dato de que en este ámbito concurren una pluralidad de competencias legislativas sobre materias de distinta naturaleza. A desarrollar estas ideas, exponiendo de manera crítica las disposiciones que al respecto establece la LJV, dedico el epígrafe siguiente.

15 Parece sugerirlo algún procesalista. Banacloche Palao en particular, afirma que: «La Disposición adicional primera tiene exclusivamente un carácter terminológico, y responde al deseo del legislador de evitar problemas de interpretación basados en el tenor literal de la norma. Por eso en ella se señala que las menciones que en otras leyes se hagan en materia de jurisdicción voluntaria a los Jueces, debe también entenderse referidas también a los secretarios judiciales cuando sea procedente; las referencias a la Ley de enjuiciamiento civil de 1881, han de aplicarse a la de la Ley de la jurisdicción voluntaria; cuando se hable de separación o divorcio judicial, puede ser también extrajudicial; y las relativas al Código civil y legislación civil, también se extienden a las normas civiles forales o especiales. No hay nada que reprochar a esta disposición adicional primera, y puede servir para solucionar algún problema que pudiera plantear alguien que interprete el Derecho conforme al criterio de literalidad; pero, en cualquier caso, hubiera resultado más conveniente actualizar los preceptos que hubieran sido necesarios y ajustarlos a la nueva regulación, que no mantenerlos como estaban con el riesgo de generar una cierta confusión" (Banacloche Palao, 2015: I.II.6 sp). El autor se refiere conjuntamente a las normas estatales y a las forales anteriores a la ley de la jurisdicción voluntaria, dando por supuesto que la regulación es procesal.

Escribe Alonso Furelos: «Sin embargo este «buen» deseo del legislador de la Ley de Enjuiciamiento civil de 2000 no podrá cumplirse en los actos de jurisdicción voluntaria del derecho foral de las comunidades autónomas y a disposiciones de este ámbito emanadas de sus parlamentos autonómicos si forman parte de las competencias exclusivas establecidas en sus estatutos de autonomía. Sería deseable que en su colaboración con el Estado los servicios jurídicos de las comunidades autónomas mandaran al BOE y a las diferentes editoriales juridicas de la de la Ley de la jurisdicción voluntaria el texto vigente de sus especialidades en JV para que al menos — como apéndices y al final- se incluyan en ella» (Alonso Furelos, 2015: 11, el subrayado es mío). En efecto, sería deseable la colaboración del Estado y de las comunidades autónomas, en esta y en otras muchas materias, pero la técnica y la forma es más compleja de lo que sugiere el autor, pues puede ser precisa una intervención del legislador autonómico. 


\section{CONCURRENCIA DE MATERIAS Y COMPETENCIAS LEGISLATIVAS}

La LJV contiene una serie de disposiciones finales en las que el legislador estatal invoca los títulos competenciales que, de acuerdo con el reparto de competencias que efectúa la Constitución, ampararían la legislación estatal. Obviamente, en caso de plantearse un conflicto, el Tribunal Constitucional no quedaría vinculado por la manifestación hecha por el legislador estatal, pero la misma constituye un buen punto de partida para analizar la complejidad de esta materia.

\section{DERECHO PROCESAL}

La disposición final vigésima de la LJV afirma que la ley se dicta (luego introduce excepciones) al amparo de la competencia que en materia de legislación procesal corresponde al Estado conforme al art. 149.1.6 de la Constitución.

Esta previsión es coherente con el propio contenido y estructura de la LJV, que incluye las normas para la tramitación de los expedientes de esta naturaleza regulados por las leyes cuyo conocimiento se atribuye al juez o al letrado de la Administración de Justicia. Por el contrario, aquellos actos que con la nueva regulación quedan fuera del ámbito competencial de los tribunales de justicia, se regulan extramuros de esta Ley en otras normas dentro del ordenamiento jurídico a las que se da nueva redacción en sus disposiciones finales. Como aclara la exposición de motivos de la LJV, la distribución de los actos de jurisdicción voluntaria entre diferentes operadores jurídicos se refleja en la estructura de esta Ley. El criterio que se sigue es, por razones de sistemática legislativa, el de extraer de su articulado la regulación de todos aquellos expedientes cuya tramitación se mantiene fuera de la Administración de Justicia, con la consecuencia de que tan solo se regularán en su seno los actos de la competencia del juez o del secretario judicial (primer párrafo del apartado X). Es para estos actos para los que tiene sentido la mención que la disposición final vigésima de la LJV hace a la competencia en materia de legislación procesal.

De conformidad con lo dispuesto en el art. 149.1.6 a de la Constitución, el Estado tiene competencia exclusiva sobre la «legislación procesal, sin perjuicio de las necesarias especialidades que en este orden se deriven de las particularidades del derecho sustantivo de las comunidades autónomas». De aquí se deduciría que las comunidades autónomas con competencia sobre derecho civil solo podrían introducir como especialidad aquella regulación — procesal- que viniera exigida por la particularidad del propio derecho civil: por ejemplo, en el ámbito de las instituciones propias y específicas de su derecho 
civil (en los testamentos mancomunados, o en los testamentos por comisario, etc.), o en el ámbito de instituciones que, aun siendo conocidas en el derecho estatal, estuvieran reguladas de otra manera (patria potestad e instituciones equivalentes, la tutela, un régimen de comunidad de bienes, de responsabilidad de los herederos, etc.).

El derecho civil foral o especial, en el ámbito de su competencia, puede subordinar la eficacia de un acto privado a la intervención de una autoridad o de un funcionario o supeditar el ejercicio de un cargo a cierto requisito de control en garantía de derechos de terceros. La particularidad de un derecho civil derivaría entonces de la decisión de introducir o de excluir un expediente de jurisdicción voluntaria: constituye una opción de política legislativa propia del derecho civil la determinación de si debe confeccionarse inventario de forma previa al desempeño de un cargo o al disfrute de un derecho (para la viudedad aragonesa, por ejemplo), o si la renuncia a la herencia es un mero acto formal y solemne que, como requisito de validez, debe otorgarse en escritura pública $^{16}$, o si, por el contrario, debe exigirse además un control que garantice a los terceros que no se ha producido la aceptación con anterioridad ${ }^{17}$. Supuesta la «particularidad del derecho sustantivo de la comunidad

16 Así parece que lo pretende el art. 1008 del Código civil, después de la reforma por la LJV, de forma semejante a la exigencia de escritura pública para la donación de inmuebles en el Código Civil o para el otorgamiento de capitulaciones en todos los derechos civiles españoles. En la práctica no será extraño que la jurisprudencia acabe tratando esta forma como de mera documentación, a través de interpretaciones parecidas a las que se han hecho en otras materias sobre la exigencia de forma, relajándola: ¿qué pasa por ejemplo si fallece quien firma un documento privado renunciando a una herencia y no le da tiempo a otorgar escritura? Salvo que se considere que ha habido aceptación tácita, cabe esperar que se relaje la forma en la repudiación.

17 Durante la vigencia del régimen anterior, la doctrina criticaba que la repudiación de la herencia se abordara como acto de jurisdicción voluntaria, cuando solo se trata de una mera manifestación de voluntad que debe documentarse. Lege ferenda se sugería que se redujera la posibilidad de renunciar mediante escrito al juez cuando estuviera tramitando un procedimiento en el que debiera tenerse en cuenta (por ejemplo, una declaración de herederos, y para excluir al renunciante). De hecho, se consideraba que el auto que se dictara al final del procedimiento no necesitaba decisión formal alguna, fuera de la manifestación de renuncia (González Poveda, 1997: 1197 y 1198, con cita de la doctrina anterior).

En Francia, donde para ser oponible a terceros, especialmente a los acreedores y al fisco, la renuncia necesariamente debe formalizarse mediante escrito dirigido al Tribunal (Malaurie, Aynès y Brenner, 2014: 137 y ss.) se está planteando la atribución de la competencia, de forma alternativa, al notario, quien deberá remitir copia de la 
autónoma», esta podría introducir la «necesaria especialidad» procesal. Lo que sucede es que ni existe un consenso doctrinal ni político acerca del alcance de la competencia legislativa de las comunidades autónomas con un derecho civil foral o especial, al amparo del art. 149.1.8 a de la Constitución ${ }^{18}$, ni es pacífico el alcance de la competencia autonómica sobre las necesarias especialidades procesales que se deriven de las particularidades del derecho sustantivo de las comunidades autónomas ${ }^{19}$.

Llegados a este punto hay que advertir que, como la propia LJV admite, no todo su contenido es derecho procesal, ni puede invocarse la competencia

renuncia al tribunal (vid. Projet de loi portant application des mesures relatives à la justice du XXIème siècle, www.senat.fr/rap/115-121/115-121113.html, 12-07-2016).

18 Excede este trabajo la referencia a la abundante literatura sobre el tema. Me limitaré a recordar cómo, por lo que se refiere al alcance de la competencia autonómica sobre derecho civil, el Tribunal Constitucional, en sentencia 88/1993, de 12 de marzo, estableció que la noción constitucional de «desarrollo» permite una ordenación legislativa de ámbitos hasta entonces no normados por los derechos civiles forales o especiales. Cabe, según esta sentencia, que las comunidades dotadas de derecho civil foral o especial regulen «instituciones conexas» con las ya reguladas en su Compilación, según los principios informadores peculiares del derecho foral. Con posterioridad, la STC $31 / 2010$, de 28 de junio, formalmente sigue este planteamiento al declarar la constitucionalidad del precepto del Estatuto de Autonomía catalán que atribuye a la Comunidad Autónoma la competencia exclusiva sobre derecho civil, con la única excepción de las materias reservadas al Estado por el art. 149.1.8 a de la Constitución. El Tribunal Constitucional declara que este precepto, que claramente dice una cosa diferente, es constitucional si se interpreta conforme a la citada STC 88/1993 («instituciones conexas»). Contra la ficción que realiza el Tribunal Constitucional hay que advertir que las comunidades autónomas, no solo han legislado sobre muchas materias en las que no existe esa "conexión" institucional con lo ya existente con anterioridad, sino que es lógico que así haya sido por aplicación de la propia doctrina de la conexión, habida cuenta de que esta permite paulatinamente ir ampliando la regulación a instituciones conectadas con las reguladas en las compilaciones y posteriormente, a instituciones conectadas con las nuevas instituciones reguladas en las sucesivas leyes.

19 No está de más recordar cómo la STC 47/2004, de 25 de marzo, se pronunció muy flexiblemente a favor de la constitucionalidad de la modificación de la cuantía litigiosa en la ley gallega reguladora del recurso de casación, pero, en cambio, la STC 21/2012, de 16 de febrero, rechazó la competencia del legislador catalán sobre el reconocimiento de la acumulación de la acción de división y las acciones matrimoniales. En la doctrina, los comentarios publicados muestran también las discrepancias de pareceres existentes sobre este asunto. A modo de ejemplo, pueden mencionarse algunos arts. publicados en esta misma revista (Busto, 1999: 81-116; 2004: 89-142; Melero y Reverón, 2006:173-186; Caballol i Angelats, 2012: 1-24). 
del Estado sobre la legislación procesal para justificar la promulgación de la LJV en su integridad.

Claramente queda cubierta por esta adscripción genérica al derecho procesal la modificación de la Ley de Enjuiciamiento Civil realizada por la disposición final tercera de la LJV. También la regulación contenida en las disposiciones generales para los casos en que se requiera la intervención de un órgano jurisdiccional para la tutela de derechos e intereses sin que exista controversia que deba sustanciarse en un proceso contencioso (art. 1.2 de la LJV), así como las normas de tramitación de expedientes. Pero no toda la LJV. No lo es, en particular, la reforma del Código Civil. La propia LJV lo reconoce cuando en su disposición final vigésima afirma que la disposición que modifica el Código Civil se dicta «al amparo de la competencia que corresponde al Estado en materia de legislación civil, conforme al art. 149.1.8 a de la Constitución».

La reforma del Código Civil es derecho civil, no tanto por el hecho de que, formalmente, este cuerpo legal no forma parte de lo que se considera como procesal, sino porque realmente el contenido de los preceptos del Código Civil que se modifican, en la medida en que se dirigen a hacer efectiva la voluntad en casos en los que el legislador decide limitar la autonomía por razones diversas, no son normas de procedimiento, sino auténticas normas sustantivas dirigidas a delimitar el contenido, el alcance, el ámbito de ejercicio y desenvolvimiento de las situaciones personales y de los derechos a los que afectan. En definitiva, normas de derecho material: como garantía de la tutela del interés del menor, en el caso de autorizaciones, o de nombramiento de cargos tutelares y de representantes legales del ausente; o como garantía de derechos de terceros mediante la exigencia de confección de inventarios, etc.

Lo que sucede es que en la LJV, dentro de la regulación de los expedientes, los aspectos sustantivos y los que regulan el procedimiento de la intervención judicial o del letrado de la Administración de Justicia aparecen mezclados. El legislador estatal, al regular los expedientes de jurisdicción voluntaria, no siempre se limita a establecer el procedimiento para una hipótesis descrita genéricamente. Por el contrario, con frecuencia, la LJV puntualiza con cierto detalle los supuestos en los que procede la tramitación del expediente, y lo hace de forma coincidente con la regulación civil estatal ${ }^{20}$.

20 Así, por ejemplo, el art. 23.3 de la LJV enumera los supuestos en los que es necesaria la aprobación judicial del reconocimiento de la filiación no matrimonial, de forma coincidente con el Código Civil, pero en Cataluña la regulación es diferente (art. 235-12 de su Código Civil). O, por ejemplo, la regulación del ámbito de aplicación del expediente del art. 93 de la LJV se corresponde con las normas del Código Civil, porque las normas de capacidad y la regulación de la aceptación de la herencia por los 
Puede hacerlo, en la medida en que el estatal es un legislador que reúne la doble condición de competente para todo el derecho civil (con independencia

acreedores no es uniforme en los derechos autonómicos (arts. 346 y 347 del Código Foral de Aragón, 461-7 del Código catalán, entre otros).

Otro ejemplo de lo que se dice en el texto es el de la regulación de la tutela. En sede de tutela, la Ley estatal regula el control judicial y, de paso, establece que el tutor debe rendir cuentas anualmente (art. 51 de la LJV: está tomado de lo que ya decía antes el art. 269.4 del Código Civil). En derecho aragonés no está prevista expresamente la rendición anual de cuentas, aunque sin duda el juez puede imponerla, dentro de la amplitud de medidas de control que puede adoptar al nombrar tutor (art. 102.3 del Código Foral) y, en la práctica, por la inercia de aplicar el Código y seguramente porque se considera razonable, parece que se introduce siempre. Aunque lo diga ahora el art. 51 de la LJV, el juez en Aragón puede prescindir de la imposición de este control si no lo cree necesario a la vista de las circunstancias del caso concreto (una persona que posee unos ingresos mínimos de alguna ayuda social, por ejemplo, y que carece de otros medios: no es razonable multiplicar las obligaciones del tutor ni el trabajo de los jueces cuando no hay riesgo). La del art. 51 no es una norma procesal: procesal será cómo debe tramitarse y ante quién esa rendición de cuentas, no la introducción del deber de control.

También es significativa la regulación del defensor judicial. El art. 27.1 de la LJV, en su segunda parte, termina diciendo que «en todo caso, se solicitará», y enumera los supuestos en los que debe solicitarse nombramiento de defensor judicial para los menores y para las personas con capacidad modificada judicialmente (o por modificar). Para los supuestos de conflictos de intereses esta regulación no es coincidente con la del art. 13 del Código Foral aragonés. La norma aragonesa, para los casos de oposición de intereses entre el menor y quien le represente (las mismas reglas son aplicables a los incapacitados, art. 39 del Código Foral) admite la opción de acudir a la institución aragonesa de la Junta de Parientes (art. 13.1.b y c, también en caso de asistencia, art. 28.b), lo que indudablemente no plantea ningún problema, pero también contempla la posibilidad de que el juez autorice la actuación del padre o tutor único con el que existe el conflicto de intereses (art. 13.1.b). Esta solución no es la de la LJV: habría que nombrar un defensor judicial (puntualmente, la DGRN ha admitido que la aprobación judicial posterior necesaria para el acto subsanaría la falta de nombramiento del defensor). La solución aragonesa es buena, pero no es la del art. 27 de la LJV y, por ello, tampoco establece un cauce para solicitar del juez que autorice anticipadamente la actuación del padre o tutor. Si una opción es que actúe el padre/tutor con autorización de la Junta, institución propia aragonesa que no plantea dudas, no debe excluirse la alternativa de la autorización judicial; esa diferencia con la regulación estatal es coherente con la posible intervención de la Junta. Por otra parte, si el padre único o tutor actúa con la autorización del juez se simplifica en la práctica y no hay ninguna merma de tutela para el representado. Pero esa autorización solo debe darse si es para un acto de enajenación concreto, lo que ya resulta del art. 18 del Código Foral. Si no es así, 
de que algunas de estas normas no sean aplicables cuando lo sea el derecho civil foral o especial) y de competente para el derecho procesal. No obstante, hubiera resultado más acertado no reproducir los supuestos de derecho material en aquellas partes de la LJV que regulan el procedimiento.

Esta técnica legislativa, cada vez más extendida, obedece a una falta de confianza en que los operadores jurídicos tengan la competencia y la habilidad de saber buscar y coordinar textos legales diferentes (Código Civil y LJV, por ejemplo), de modo que el legislador prefiere facilitarles la labor copiándoles en la LJV los supuestos concretos que integran la categoría general. Sin embargo, este modo de proceder, además de la infantilización de los juristas, tiene la consecuencia de generar confusión e inducir a los operadores a acabar aplicando el Derecho civil estatal en casos en los que existe una regulación autonómica propia.

\section{DERECHO CIVIL}

Como he señalado ya, la disposición final primera de la LJV modifica el Código Civil español y la disposición final vigésima de la LJV afirma que aquella disposición se dicta «al amparo de la competencia que corresponde al Estado en materia de legislación civil, conforme al art. 149.1.8 ${ }^{a}$ de la Constitución».

El precepto constitucional invocado es muy complejo, y la competencia del Estado sobre el derecho civil, salvo para determinadas materias que se mencionan expresamente en el mismo, no es exclusiva. El Estado, que tiene competencia para legislar sobre cualquier materia de derecho civil, la tiene en exclusiva sobre algunas de ellas, mientras que sobre otras también pueden legislar las comunidades con competencia sobre un derecho civil propio, foral o especial.

De esta forma, determinadas modificaciones del Código Civil afectan a todos los españoles, en la medida en que se ocupan de materias sobre las que es competente el Estado en exclusiva. Así, la edad para casarse, o la introducción de la separación y el divorcio de mutuo acuerdo ante el letrado de la Administración de Justicia o el notario. La aplicación directa de la regulación civil sobre estas materias determina a su vez que otros preceptos autonómicos en los que se alude a ellas deban interpretarse adaptados a la nueva regulación (así, cuando una norma autonómica menciona la separación o el divorcio

hay que nombrar defensor judicial, que debe rendir cuentas al final de su gestión (art. 32 de la LJV). 
judicial habrá que considerar que se trata del divorcio o la separación «legal», para contraponerla a la separación de hecho).

En las materias de derecho civil sobre las que la competencia del Estado no es exclusiva y existe una regulación autonómica, la modificación del Código Civil operada por la LJV no cambia la naturaleza de la norma, ni lógicamente tampoco su relación con el Derecho civil autonómico (según los casos, inaplicabilidad o, si la Comunidad Autónoma no ha regulado la materia, aplicación supletoria, conforme a lo dispuesto en el art. 149.3 de la Constitución).

\section{CONCURRENCIA DE COMPETENCIAS. IDENTIFICACIÓN DE ALGUNOS PROBLEMAS}

La LJV ha introducido modificaciones de calado en algunas actuaciones que, en ocasiones, suscitan dudas en las relaciones con los derechos civiles autonómicos. Me ocupo a continuación de las más aparentes:

a) llama la atención, por ejemplo, la regulación de la sucesión legal. Por lo que se refiere al procedimiento adecuado para realizar las indagaciones necesarias para identificar a los herederos, el art. 55 de la Ley del Notariado, redactado por la disposición final undécima de la LJV, regula la declaración de herederos abintestato como un expediente notarial tramitado como acta de notoriedad. A su vez, la disposición derogatoria única de la LJV deroga los arts. de la Ley de Enjuiciamiento Civil de 1881 en los que se venía regulando la declaración de herederos abintestato (que, desde 1992, mantenía la competencia judicial solo para los colaterales). Tanto la delimitación de los supuestos (por ejemplo, en los derechos autonómicos en los que se regula, no solo a falta de testamento, también a falta de pacto sucesorio) como la designación de las personas llamadas por la ley a suceder corren en cada caso a cargo del derecho civil aplicable. Las leyes autonómicas no contienen referencia al procedimiento para la sucesión legal, de modo que la entrada en vigor de la reforma operada por la LJV se ha implantado con normalidad en todo el territorio nacional. Hay que reconocer que no deja de ser insatisfactorio desde el punto de vista de la seguridad jurídica y de una adecuada técnica legislativa que la razón por la que no se haya suscitado polémica en este punto sea el silencio del legislador autonómico. Este razonamiento no deja de ser oportunista y endeble, y muestra la falta de claridad y la inseguridad con la que se abordan las relaciones entre el Derecho estatal y el autonómico. 
b) La LJV, por otra parte, ha modificado el art. 958 del Código Civil, de modo que cuando es llamado el Estado, es la propia Administración la que debe realizar la declaración de heredero. Se ha reformado igualmente la Ley 33/2003, de Patrimonio de las Administraciones Públicas (disposición final octava de la LJV), que en su art. 20 se refiere también a la competencia de las comunidades autónomas cuando estas sean llamadas a suceder en virtud de las normas de derecho foral o especial aplicables. De entre las comunidades autónomas que contienen semejante llamamiento, Aragón y Cataluña, de manera coherente con la regulación estatal vigente, en sus respectivas normas venían atribuyendo al juez la competencia para la declaración de herederos. El legislador aragonés, inmediatamente después de la promulgación de la LJV, ante la desaparición de la regulación estatal de los expedientes judiciales de declaración de herederos, ha procedido a modificar su Código Foral, suprimiendo la referencia a la declaración «judicial» que contenía el art. 535. Se ha dado por supuesto que se trata de una cuestión de derecho procesal (art. 149.1.6 a de la Constitución) ${ }^{21}$. Paradójicamente, la propia LJV considera que la norma es civil (art. 149.1.8 a de la Constitución) ${ }^{22}$, suprimiendo la referencia que en el anteproyecto se hacía, ni siquiera al art. 149.1.6a, sino al art. 149.1.18 a de la Constitución ${ }^{23}$. Inseguridades y contradicciones que muestran la falta de claridad en esta materia.

21 El art. 33 de la Ley 2/2016, de 28 de enero, de medidas fiscales y administrativas de la Comunidad Autónoma de Aragón, modifica el texto refundido de la Ley de Patrimonio de Aragón, aprobado por Decreto Legislativo 4/2013, de 17 de diciembre, del Gobierno de Aragón; por su parte, la Ley 3/2016, de 4 de febrero, de reforma de los arts. 535 y 536 del Código del Derecho Foral de Aragón, introduce una reforma que no afecta al derecho civil sustantivo aragonés, pero se dirige a ajustar las normas forales a la reforma estatal y autonómica de procedimiento. La Ley 304.7 de la Compilación de Navarra, modificada por la Ley Foral 10/2016, de 1 de julio, ni contenía ni contiene ahora referencia a la competencia para la declaración de heredera de la Comunidad Foral, pero la citada ley modifica la Ley Foral 14/2007, de 4 de abril, del Patrimonio de Navarra, para regular el procedimiento administrativo.

22 Cosa que hace, modificando el criterio del anteproyecto de ley y acogiendo la observación del informe elaborado por el Consejo General del Poder Judicial, que defendió el carácter civil de la atribución de la competencia para hacer la declaración, con el objetivo manifestado expresamente de que Cataluña pudiera atribuir la competencia al juez (vd. Consejo General del Poder Judicial, 2014: 239 y ss.).

23 Por si alguien pensara que no cabe más confusión, hay que señalar que la disposición adicional 4.3 del Real Decreto Legislativo 7/2015, de 30 de octubre, por el que se aprueba el texto refundido de la Ley de Suelo y Rehabilitación Urbana, modifica el 
c) La disposición final octava de la LJV modificó además la Ley 33/2003, de 3 de noviembre, de Patrimonio de las Administraciones Públicas, para añadir unas reglas por las que se atribuye la competencia a la Administración en los casos de la sucesión abintestato a favor del Hospital de Nuestra Señora de Gracia de Zaragoza y de las diputaciones forales de los territorios históricos del País Vasco. En el primer caso, el legislador aragonés, mediante las mismas Leyes citadas 2/2016 y 3/2016, ha acomodado el derecho aragonés a esta previsión estatal, de modo que se ha evitado cualquier problema práctico que se pudiera suscitar. En el segundo caso, la norma era coherente con lo que preveía la Ley 3/1992, de 1 de julio, del Derecho Civil Foral del País Vasco ${ }^{24}$. Lo que sucede es que esta Ley fue derogada por la Ley 5/2015, de 25 de junio, de Derecho Civil Vasco y, desde su entrada en vigor, el 3 de octubre de 2015, el llamamiento legal ya no se hace a favor de las diputaciones forales de los territorios históricos, sino a favor de la comunidad autónoma, por lo que la previsión de la LJV queda privada de sentido ${ }^{25}$. No parece, sin embargo, que esta cuestión haya sido problemática en el País Vasco, donde en cambio se temió un recurso de inconstitucionalidad contra la ampliación de llamamiento sucesorio legal a favor de la comunidad autónoma ${ }^{26}$.

d) En la práctica, de manera inmediata tras la entrada en vigor de la LJV, las complicaciones han surgido cuando ha cambiado el funcionario llamado por la ley a intervenir. Eso ha sucedido, en particular, con los supuestos a que se refieren los arts. 1005 y 1008 del Código Civil. Con anterioridad a la Ley 15/2015, la interpelación para la aceptación o repudiación de la herencia la hacía el juez, y la renuncia podía hacerse por escrito presentado ante el juez. La LJV modifica estos preceptos del Código Civil, de manera que, en la actualidad, solo son competentes para la interpelación

apartado 5 de la disposición final segunda de la Ley 33/2003, que ahora ya no dice que la regulación del procedimiento administrativo para la declaración de heredera de la administración sea legislación básica en el sentido del art. 149.1.18 de la Constitución. En consecuencia, no es de aplicación en las comunidades autónomas. Ampliamente, sobre todo ello, Parra Lucán (2016, en prensa). Cuyo art. 73 establecía: «En la sucesión ab intestato, a falta de colaterales, será llamada la Diputación Foral del Territorio Histórico correspondiente a la vecindad del causante». Para más información me remito nuevamente a mi comentario citado dos notas más arriba.

26 Vid. el Acuerdo de la Comisión Bilateral de Cooperación Administración del Estado-Administración de la Comunidad Autónoma del País Vasco en relación con la Ley 5/2015, de 25 de junio, de Derecho Civil Vasco (BOPV, n. ${ }^{\circ}$ 15, de 25 de enero de 2016). 
y para recibir la declaración de voluntad de la repudiación los notarios. El derecho aragonés y el derecho catalán, por su parte, contienen una regulación semejante a la derogada del Código Civil.

Por este motivo, después de la entrada en vigor de la LJV se ha producido una situación de inseguridad en los territorios cuyo derecho propio contiene una regulación diferente a la estatal. Aunque resulta difícil acceder a los autos de los juzgados para conocer si ha sucedido en más ocasiones, es significativo el Auto 437/2015 del Juzgado de Barcelona no 27, de 10 de diciembre de 2015, que ante la solicitud de llevar a cabo una interpelación, al amparo del art. 46112 del Código Civil de Cataluña, se declara incompetente, por entender, de conformidad con el criterio del Ministerio Fiscal, que tal precepto ha quedado derogado tácitamente por la modificación del art. 1005 del Código Civil.

Algunos notarios que se han ocupado de la divergencia nacida entre los derechos autonómicos y el civil estatal se han manifestado en sentido coincidente. Así, con el fin de justificar la competencia en todo el territorio nacional del notario para la interpellatio se ha dicho que la norma que se la atribuye es «procesal», «básica» (¿?), dictada sobre materia de la competencia del Estado, lo que determinaría que la norma autonómica que contuviera una regulación diferente o bien estaría derogada ${ }^{27}$ o bien adolecería de una inconstitucionalidad sobrevenida ${ }^{28}$. Es minoritaria en este sector profesional la opinión manifestada que sostiene la vigencia y aplicabilidad del derecho autonómico ${ }^{29}$.

En principio, y desde un punto de vista de estricta técnica jurídica, conviene recordar, de una parte, que una norma estatal no puede «derogar» una norma autonómica, por estar insertas en subordenamientos diferentes y carecer el legislador estatal de competencia sobre el derecho civil autonómico; de otra, que la «inconstitucionalidad sobrevenida», figura importada por la

27 En este sentido, Cabanas y Ballester (2015) afirman que las disposiciones de los derechos autonómicos están derogadas en cuanto hagan mención al juez.

28 Así, para Prados Ramos (2015) hay inconstitucionalidad sobrevenida en la norma catalana que atribuye competencia al juez para la interpellatio/renuncia a la herencia porque la LJV se dicta al amparo del art. 149.1.6 a de la Constitución y porque, de no aceptarse este criterio, resultaría que la interpellatio in iure en Cataluña carecería de trámite procesal oportuno. Por su parte, Espiñeira Soto (2016) se inclina por considerar que en el ámbito de aplicación de los derechos civiles que regulen la interpelación, la competencia corresponde, actualmente, al notario. Se basa para ello en la competencia estatal en materia de ordenación de los registros e instrumentos públicos y legislación procesal, porque considera que el cambio de órgano competente es mera cuestión de orden procesal.

29 En este sentido puede citarse a Feás Castilla (2016: 826). 
doctrina constitucional española de la italiana, requeriría de una norma anterior a la Constitución (o, en otro caso, de una reforma constitucional) que devendría inconstitucional tras la promulgación de esta última. En principio, el reproche a la norma autonómica no podría venir de la modificación del precepto estatal y, en todo caso, si el motivo es la falta de competencia de la comunidad autónoma para legislar una materia tal defecto sería anterior a la reforma de la ley estatal.

La complejidad de la materia y del sistema de distribución de competencias normativas permite esperar nuevos conflictos y discrepancias. En la práctica, la declaración de incompetencia por un juzgado avocará a los ciudadanos a acudir al notario y no parece que existan razones pragmáticas para que un particular impugne la resolución que declare la incompetencia judicial. También cabe esperar que, requeridos para ello, los notarios ejerzan la competencia, asumiendo que se trata de una función que les atribuye la Ley del Notariado, con independencia de cuál sea el derecho aplicable; por tanto, aunque el derecho material aplicable no les atribuya esa función. Pero no hay que descartar que un juez interprete de otra manera la norma y se declare competente o, lo que será más raro, que un notario deniegue su función por entender que no es competente ${ }^{30}$.

En cualquier caso, las dificultades e incertidumbres interpretativas son indeseables y aconsejan una intervención expresa del legislador autonómico. Una servidumbre de los legisladores civiles autonómicos, que acaban legislando muchas veces per relationem con el derecho estatal y que se evitaría si las normas autonómicas no reiteraran la regulación estatal con el fin de dotarse de un sistema completo. El problema que se plantea para resolver esta cuestión es el de la falta de certeza en la determinación de las competencias legislativas. En particular, la duda de si el legislador autonómico puede atribuir la competencia a un funcionario diferente para un supuesto análogo al previsto en la ley estatal.

A este respecto cabe observar que algunas normas de los derechos forales que atribuyen la competencia al juez lo hacían reiterando la legislación esta-

30 En la práctica, además de discrepancias teóricas y doctrinales de interpretaciones y desigualdad en la aplicación de la ley pueden producirse problemas importantes. Por ejemplo, si en un caso en el que es aplicable el derecho catalán, un notario aplica el art. 1057 del Código Civil y aprueba una partición de la herencia, cabrá discutir la validez de tal partición porque en Cataluña, si no existe acuerdo de todos, la partición es judicial (art. 464-5, 6 y 7 de su Código). Lo mismo puede decirse en Galicia, donde se prevé una intervención notarial en la partición, pero el notario no aprueba la partición, sino que en el caso de que sea aprobada por tres cuartas partes de los representantes del haber hereditario, se limita a formalizar la partición (arts. 296 y ss. de la Ley de Derecho Civil de Galicia). 
tal. Si se entiende que son normas procesales de competencia exclusiva del Estado, estaríamos ante la reiteración de una norma procesal estatal. La STC 201/2013, de 5 de diciembre, insistiendo en el criterio sostenido por las SSTC $47 / 2004$ y $341 / 2005$, mantiene que, si bien

la mera reiteración de reglas procesales generales en la legislación autonómica no hace buena, sin más, una tal previsión (criterio mantenido desde la STC 71/1982, FJ 20, STC 173/1998, de 23 de julio, FJ 16), esta proscripción de la reiteración o reproducción de normas procesales por el legislador autonómico (leges repetitae) no debemos extenderla a aquellos supuestos en que la reiteración simplemente consista en incorporar a la normativa autonómica, ejercida ésta en su ámbito competencial, determinados preceptos del ordenamiento procesal general con la sola finalidad de dotar de sentido o inteligibilidad al texto normativo aprobado por el Parlamento autonómico.

De acuerdo con esta doctrina, en los casos de jurisdicción voluntaria en los que la norma foral sea una mera reiteración de la atribución de la competencia al juez prevista en la ley estatal, podría defenderse que, modificada esta última, la nueva regulación sería también de aplicación en el ámbito autonómico, cuya norma se limitaba a reiterar una norma estatal sin el propósito de establecer una regulación ni una especialidad y, justamente por ello, no era inconstitucional.

Dentro de la heterogeneidad de actos de jurisdicción voluntaria, en los casos en los que el legislador estatal de 2015 ha entendido que la intervención del juez estaba justificada por su auctoritas, sin que ejerciera jurisdicción, ha excluido la competencia judicial en la LJV. Lo que sucede es que, si precisamente se atribuye ahora la competencia al notario, es por considerar que estamos ante una función que no constituye actividad judicial, porque se trata de una actividad no jurisdiccional, en la que no hay que enjuiciar. En consecuencia, ni existe un proceso, ni existe una norma procesal. Resulta paradójico, pero habría que concluir que era procesal la norma que atribuía competencia al juez para determinada función (¿porque presuponía la emisión de un juicio, de una valoración, de donde derivaba su autoridad?) y deja de serlo la norma que para el mismo supuesto la atribuye a otro funcionario. Si se entiende que la norma que atribuye una función al juez es procesal, el legislador autonómico no estaría legitimado para mantenerla, salvo que existiera una particularidad del derecho sustantivo que así lo exigiera, lo que difícilmente puede identificarse en las normas que son repetición del derecho estatal ahora derogado. En definitiva, como puede verse, a la complejidad del sistema de distribución de competencias normativas entre el Estado y las comunidades autónomas en materias que afectan al derecho privado, se suma aquí la diversidad de las finalidades y funciones, la complejidad de la propia naturaleza de la jurisdicción voluntaria. 
Por lo demás, el argumento que defiende el carácter procesal de la nueva norma que atribuye la competencia al notario no es convincente, y su admisión pondría en entredicho la constitucionalidad de otras normas autonómicas en las que se atribuyen funciones al notariado. Si precisamente ha triunfado la consideración del carácter no judicial de algunas actividades de la jurisdicción voluntaria para desjudicializar su regulación y atribuir al notario la competencia de algunas funciones, parece incoherente defender al mismo tiempo la naturaleza procesal de la norma que atribuye una competencia a un cuerpo de funcionarios que actúa fuera del proceso judicial y de toda actividad jurisdiccional. De la misma manera que no es procesal la regulación de un procedimiento encomendado a otros funcionarios (cfr. art. 149.1.18 a de la Constitución). La noción de derecho procesal se desenvuelve necesariamente en la órbita de la actividad judicial, con independencia de que la jurisdicción voluntaria sea o no actividad jurisdiccional, y de que sea razonable considerar que no es jurisdicción voluntaria la atribuida al notario.

En efecto, si se considerara que la previsión de la intervención de un notario es competencia exclusiva del Estado, serían inconstitucionales todas las normas autonómicas en las que desde hace tiempo, con normalidad, y sin que fuera discutida la atribución por nadie, tampoco por los notarios, se les vienen encomendando, como he señalado más arriba, funciones, bien en exclusiva, bien en ocasiones de forma alternativa a la autoridad judicial ${ }^{31}$.

En mi opinión, tal conclusión no sería razonable porque el legislador competente sobre una materia de derecho civil lo es también para atribuir al notario una función que se inserte en las que le corresponden conforme a su ley reguladora. El notario, dice el art. 1 de la Ley Orgánica del Notariado, es

31 En sede de tutela, por ejemplo, el Código Civil solo se refiere al inventario ante el secretario judicial, pero el inventario notarial está reconocido legalmente como una opción en los derechos autonómicos aragonés y catalán (arts. 141.2 del Código Foral y 222-21.2 del Código Civil de Cataluña, que ordenan que se deposite una copia en el juzgado pero, a diferencia de lo que se preveía en el art. 27 de la derogada Ley 39/1991, de 30 de diciembre, de la tutela e instituciones tutelares de Cataluña, no requieren aprobación judicial, ni ahora del letrado de la Administración de Justicia). En ausencia de norma expresa que así lo permita en el ámbito del Código Civil, la posible previsión de inventario notarial en los casos de delación voluntaria (art. 223 del Código Civil) no impedirá que se considere insuficiente la protección dispensada al tutelado (cfr. art. 45.4 de la LJV) y que se de a ese inventario notarial presentado por el tutor el mismo valor que a un inventario no formal con que principia la formación del inventario ante el secretario de acuerdo con el art. 47 de la LJV. Semejante interpretación, en cambio, no resulta posible en los derechos forales, salvo que se considere al legislador incompetente para dictar la norma. 
el funcionario «autorizado para dar fe, conforme a las leyes, de los contratos y demás actos extrajudiciales». Esas leyes son las dictadas por el legislador competente, estatal o autonómico, según la materia, conforme al reparto competencial diseñado, de manera ciertamente confusa, en la Constitución ${ }^{32}$.

\section{ORDENACIÓN DE LOS REGISTROS E INSTRUMENTOS PÚBLICOS}

No es óbice para lo que se acaba de afirmar la competencia exclusiva del Estado para la «ordenación de los registros e instrumentos públicos» prevista en el art. 149.1.8 de la Constitución.

La disposición final undécima de la LJV modifica la Ley del Notariado y la disposición final vigésima de la misma LJV considera que tal modificación está incluida en la competencia exclusiva del Estado en materia de ordenación de los registros e instrumentos públicos (art. 149.1.8 a de la Constitución). Por lo que ahora importa, se han introducido en la Ley del Notariado unas reglas generales sobre intervención de los notarios en expedientes y actas especiales (arts. 49 y 50) y una regulación de los expedientes en materia de sucesiones (arts. 55 a 68), entre los que destaca la regulación en el art. 67 de la formación del inventario de los bienes y derechos del causante a efectos de aceptar o repudiar la herencia. No hay mención específica en el nuevo título VII de la Ley del Notariado ni al expediente de repudiación (parece muy sencillo, basta una escritura pública, es un acto de documentación) ni al de interpelación. La atribución de una función al notario, empero, no implica una «ordenación de los registros e instrumentos públicos».

La dificultad de precisar el alcance de esta competencia estatal sobre la ordenación de los instrumentos públicos ha sido abordada por el Tribunal Constitucional para dejar claro que notarios y registradores únicamente se sitúan en relación de dependencia jerárquica con el Estado, a través de la Dirección General de los Registros y del Notariado, órgano superior de aquellos ${ }^{33}$.

32 Es verdad, por otra parte, que se han ido atribuyendo funciones, en la legislación estatal —y en la autonómica - en la que el notario emite juicios y calificaciones, y en las que se le atribuyen funciones no como notario, sino por ser notario. La regulación introducida por la Ley de la jurisdicción voluntaria ha supuesto un paso más, porque aunque desde el punto de vista formal puedan ser reconducidas a actas o escrituras, se le atribuyen funciones que exceden de la notarial como era conocida hasta ahora. Por todos, vid. Gomá Lazón (2016: 41-51).

33 La STC 120/1992, de 21 de febrero, sostuvo que la competencia reguladora del Estado sobre el cuerpo notarial deriva «del carácter de funcionarios públicos del Estado que tienen los notarios y su integración en un cuerpo único nacional. La descentralización del Notariado por la vía de sus diferentes Colegios ni altera el carácter único 
Estas afirmaciones contemplan la imposición de sanciones y un régimen disciplinario, excluidos de la competencia autonómica, pues tanto la responsabilidad civil como el régimen disciplinario de notarios y registradores pertenecen a la esfera de la competencia exclusiva del Estado. Sin embargo, una cosa es que la comunidad autónoma carezca de competencia para imponer sanciones a los notarios y otra que los notarios no deban cumplir la ley aplicable, también cuando esa ley es autonómica.

Como recuerda la STC 4/2014, de 16 de enero: «Todos los poderes públicos están sujetos a la Constitución y al resto del Ordenamiento jurídico (art. 9.1 de la Constitución), y todos los órganos de la Administración pública actúan con sometimiento pleno a la ley y al Derecho (art. 103.1 de la Constitución). No es pues ocioso indicar que, en su condición de funcionarios públicos, los notarios y registradores forman parte de esta esfera de especial sujeción — desde luego comprensiva de la legislación legítimamente dictada por las Comunidades Autónomas en el ejercicio de sus competencias estatutariascomo consecuencia directa de principios constitucionales que trascienden su mero reflejo en el ejercicio de la potestad disciplinaria ${ }^{34}$.

del Cuerpo en toda España ni priva al Estado de las competencias que le atribuye el art. 149.1.18 a de la Constitución, que, por estar integrados dentro de su propia Administración, ha de ejercer con toda amplitud, tanto en lo relativo a la ordenación de la función pública que desempeñan, que, en parte, se canaliza a través de los Colegios Notariales, cuanto en lo concerniente al régimen estatutario de sus funcionarios"» (STC 87/1989, FJ 4).

En parecidos términos, la STC 207/1999, de 11 de noviembre, afirma que «la infracción y sanción establecidas por la Ley Foral 7/1989, en el precepto impugnado, incide en el incumplimiento de deberes, de notarios y registradores de la propiedad, integrantes del régimen estatutario de quienes ejercen la función pública notarial y la registral, incardinándose así en el ámbito de la responsabilidad administrativa o disciplinaria de aquéllos, y que es exigible, en régimen de uniformidad, por la correspondiente legislación estatal. La competencia estatal encuentra apoyo en la competencia exclusiva sobre la ordenación de los registros e instrumentos públicos (art. 149.1.8 ${ }^{\mathrm{a}} \mathrm{de}$ la Constitución), sin olvidar la que ostenta sobre las bases del régimen estatutario funcionarial (art. 149.1.18a de la Constitución)» (FJ 9).

34 La STC 4/2014, de 16 de enero, se pronuncia sobre la constitucionalidad de la fuerza vinculante de las consultas evacuadas por la Dirección General de Derecho y Entidades Jurídicas de la Generalitat con el argumento de que versa únicamente sobre la interpretación y aplicación de los actos y negocios del derecho catalán, más concretamente, sobre los «actos o negocios relativos al derecho catalán que sean susceptibles de inscripción en los registros situados en Cataluña» y a efectos de su encuadramiento competencial, su objeto ha de ponerse en conexión con el art. 129 del Estatuto de Autonomía de Cataluña, que atribuye a la Generalitat «la competencia exclusiva en 
Con anterioridad, las SSTC 74/1989, de 24 de abril y 156/1993, de 6 de mayo, se habían pronunciado también sobre el alcance de la expresión "ordenación» de los instrumentos públicos, en ambos casos defendiendo que la competencia exclusiva del Estado sobre esta materia no puede privar a las comunidades autónomas de la suya para legislar sobre aquellas materias sobre las que tienen competencia exclusiva, aunque se refieran a actos o contratos que se otorgan en instrumentos públicos ${ }^{35}$. Esta es la clave, por lo que nos interesa en el tema que nos ocupa.

La reserva al Estado de la ordenación de los instrumentos públicos, afirmó la STC 74/1989, de 24 de abril $^{36}$, tiende al aseguramiento de un tratamiento normativo unitario y común de los documentos públicos notarialmente autorizados y, por tanto, de las escrituras públicas, uniformando a tal fin el régimen de su naturaleza y contenido, de sus requisitos internos y formales, de su validez y eficacia y, en general, de todos aquellos aspectos que comprometan la unidad de su disciplina jurídica, de modo que una nota definitoria de las

materia de derecho civil, con la excepción de las materias que el art. 149.1.8 ${ }^{\mathrm{a}} \mathrm{de}$ la Constitución atribuye en todo caso al Estado», incluyendo "la determinación del sistema de fuentes del derecho civil de Cataluña». Vid. los comentarios críticos de Bercovitz Rodríguez-Cano (2014: 1-3) y de Pérez de Ontiveros Baquero (2014: 46). El resultado práctico de la combinación de estos argumentos me parece muy destacable: los notarios están vinculados a la ley y al derecho, estatal o autonómicos, y aunque la comunidad autónoma no pueda establecer un régimen de sanciones aplicable a los notarios sí puede establecer las fuentes de su propio derecho civil, y en este ámbito, imponer la fuerza vinculante de las consultas. Cabe concluir que el no seguimiento de las consultas evacuadas sobre los actos y negocios del derecho catalán supone un incumplimiento del derecho aplicable, también para los notarios. Como dice el art. 7.2 de la Ley 5/2009, de 28 de abril, de los recursos contra la calificación negativa de los títulos o las cláusulas concretas en materia de derecho catalán que deban inscribirse en un registro de la propiedad, mercantil o de bienes muebles de Cataluña, declarado constitucional: «Las respuestas a las consultas hechas de acuerdo con lo establecido por el apartado 1 son vinculantes para todos los notarios y registradores de la propiedad y mercantiles, los cuales deben ajustar la interpretación y aplicación que hagan del derecho catalán al contenido de dichas respuestas. La Dirección General de Derecho y de Entidades Jurídicas debe dar publicidad y la máxima difusión a estas respuestas por los medios que considere más adecuados».

Una visión crítica de esta doctrina jurisprudencial, desde una óptica de contraposición entre el Derecho estatal y el autonómico y no de colaboración y coordinación, en Marín López (1994: 111-195). Con anterioridad, Rodríguez-Cano (1993: 72, 76-82). ción en relación con el art. 3 del Decreto del Consejo Ejecutivo de la Generalidad de Cataluña 125/1984, de 17 de abril. 
reglas ordenadoras de los instrumentos públicos y, por tanto, de las escrituras públicas, ha de ser la de servir, en relación de necesidad, al establecimiento y preservación de la uniformidad de su régimen jurídico (FJ 5$)^{37}$.

La STC 156/1993, de 6 de mayo, precisa más adelante que, si bien el Estado ostenta «en todo caso" competencia exclusiva para la ordenación de los instrumentos públicos (art. 149.1.8 a de la Constitución), lo que supone, como es obvio, que ninguna disposición autonómica podrá, sin incurrir en inconstitucionalidad, proceder a dicha ordenación, hay que advertir también

que el intérprete ha de cuidar aquí de salvar la concordancia entre la exclusiva competencia del Estado en este ámbito y la que pueda ostentar determinada Comunidad Autónoma para legislar sobre institutos jurídicos integrados en su Derecho civil propio, o conexos con el mismo, lo que significa, ante todo, que no será aceptable un entendimiento tan lato de aquella competencia estatal que venga a impedir toda ordenación autonómica sobre actos o negocios jurídicos con el solo argumento de que unos u otros pueden o deben formalizarse mediante instrumento público ${ }^{38}$.

En definitiva, la doctrina del Tribunal Constitucional confirma la tesis de que la competencia exclusiva del Estado sobre ordenación de los instrumentos públicos no excluye que las comunidades autónomas puedan, al legislar sobre su propio derecho civil, establecer una regulación en la que la validez o la eficacia de un acto o negocio dependa de una intervención notarial conforme a su función, o que esa intervención sea presupuesto para poder acceder a un cargo o desempeñar una función (por ejemplo, confección de un inventario por el viudo usufructuario o por el administrador de una sucesión ordenada mediante fiduciario).

37 Según el Tribunal Constitucional, no puede, por lo expuesto, entenderse que la Generalidad de Cataluña al establecer, en el ejercicio de su competencia para normalizar el uso de la lengua catalana en las escrituras públicas, las reglas contenidas en el art. 3 del Decreto 125/1984, de 17 de abril, haya invadido la competencia reservada al Estado por el art. 149.1.8 de la Constitución en materia de ordenación de los instrumentos públicos, cuya unidad de regulación no ha sido inconstitucionalmente atacada. A juicio del Tribunal Constitucional, a las reglas discutidas no se anuda consecuencia alguna que sea relevante para el régimen de la naturaleza y contenido de las escrituras públicas, ni para la disciplina de los requisitos y condiciones de validez y eficacia de las mismas, que no resulta en modo alguno afectada.

38 En el caso se declara que la supresión de la intervención preceptiva de testigos en el otorgamiento notarial de los testamentos no vulnera la competencia estatal en materia de ordenación de los instrumentos públicos. 
De acuerdo con esta doctrina, una cosa es la ordenación de los registros e instrumentos públicos, y otra bien distinta que el legislador competente sobre una materia de derecho civil (régimen económico de la familia, sucesiones...) no pueda exigir como requisito de validez que un acto o negocio se otorgue en escritura pública ${ }^{39}$ y que, en su caso, acceda al Registro de la Propiedad para que goce de todos los efectos de publicidad y oponibilidad a terceros que derivan de esta institución.

De la misma manera, la competencia exclusiva del Estado sobre ordenación de los registros e instrumentos públicos tampoco constituye un obstáculo para que, en el ejercicio de la competencia sobre el propio derecho civil, el legislador autonómico arbitre fórmulas de soluciones para algunos problemas que se plantean, requiriendo la intervención de un notario en casos en los que el legislador estatal no lo prevé, atribuyéndole funciones que sean compatibles con las que resultan de su ley reguladora, siempre que no usurpen funciones de otros órganos, en particular los judiciales (puesto que el ejercicio de la potestad jurisdiccional, juzgando y haciendo ejecutar lo juzgado corresponde exclusivamente a juzgados y tribunales, conforme al art. 117.3 de la Constitución).

Como es fácil de comprender, todos los argumentos que se acaban de exponer son coherentes formalmente con el desarrollo alcanzado de hecho por el derecho autonómico al amparo de la competencia sobre el foral o especial. Los desajustes se están produciendo en buena medida porque la legislación de las comunidades autónomas en materia de derecho civil no se ha limitado a conservar y actualizar un derecho especial, sino que ha desarrollado un completo derecho civil con pretensiones de plenitud. Hay que advertir, por ello, que sería un contrasentido que los debates que se ha planteado a nivel nacional durante años en la discusión y elaboración de los diferentes anteproyectos y proyectos de ley de jurisdicción voluntaria pudieran volver a plantearse ahora a nivel autonómico.

Hay espacios para los que no se cuestiona la necesidad de mantener la reserva judicial (derechos de la personalidad, actuaciones relacionadas con menores/personas con discapacidad). Pero en los ámbitos en los que se acepta la posibilidad de desjudicializar surge la polémica acerca de las dos posibles soluciones, entre la exclusividad y la alternatividad (o compatibilidad): esto es, entre desjudicializar totalmente, en el sentido de atribuir solo al notario la competencia o, por el contrario, proporcionar la opción de que el ciuda-

39 En Aragón, por ejemplo, el llamamiento voluntario a la intervención de la Junta de Parientes, art. 170.2 del Código Foral; pactos y renuncias al derecho expectante, arts. 272 y 274 del Código Foral. 
dano tenga la facultad de elegir entre las dos vías (judicial/extrajudicial) ${ }^{40}$. El legislador estatal se ha inclinado por la exclusividad en ciertos ámbitos, atribuyendo al notario competencias en algunas actuaciones que antes pertenecían a la esfera judicial. Las preguntas que inmediatamente se plantean son varias. ¿Qué sucede en las comunidades autónomas en las que el derecho civil propio expresamente atribuye la competencia al juez? ¿Es admisible que haya cuerpos nacionales de funcionarios de la Administración de Justicia (magistrados, jueces, letrados de la Administración de Justicia), notarios, registradores, que tengan atribuidas funciones de modo diferente en cada comunidad autónoma? ¿Estamos ante una consecuencia natural e inevitable de la admisión de la pluralidad de competencias sobre el derecho civil? O, por el contrario, ¿solo es admisible una norma autonómica cuando una especialidad sustantiva lo justifique?

No solo las preguntas son difíciles, sino que me parece que no pueden responderse de manera inequívoca e igual en todos los casos. Ya me he referido antes a la atribución de funciones a los notarios. Me ocupo a continuación a la distribución de funciones entre jueces y secretarios judiciales, letrados de la Administración de Justicia conforme a su actual denominación.

\section{DISTRIBUCIÓN DE FUNCIONES ENTRE JUECES Y LETRADOS DE LA ADMINISTRACIÓN DE JUSTICIA}

En algunos supuestos, la LJV asigna al letrado de la Administración de Justicia funciones que con anterioridad eran judiciales, y la disposición adicional primera. 1 de la LJV establece que las referencias contenidas en leyes anteriores al juez en relación con asuntos de jurisdicción voluntaria se entenderán hechas al letrado o al juez con arreglo a lo dispuesto en el art. 2.3 de la $\mathrm{LJV}^{41}$.

40 La exclusividad puede reportar la ventaja de la especialización y mayor seguridad (evitar la sensación en el ciudadano de haberse equivocado con la opción elegida); la alternatividad permite escoger, de un lado, entre la tradicional garantía de la intervención judicial y la gratuidad de los expedientes y, de otro, la mayor celeridad de la práctica notarial, siempre que se mantenga la seguridad y se establezcan tasas asequibles para la mayoría. Obviamente, en este tema, no puede ocultarse que, junto al debate teórico sobre la naturaleza de la actividad, la relevancia de los derechos y garantía de los ciudadanos y la gratuidad de las actuaciones, existen importantes intereses corporativos y profesionales de funcionarios y operadores que pertenecen a cuerpos nacionales.

41 Conforme al art. 2.3 de la LJV: «El impulso y la dirección de los expedientes corresponderá a los secretarios judiciales [ahora denominados letrados de la administración de justicia], atribuyéndose al juez o al secretario judicial, según el caso, la decisión de fondo que recaiga sobre aquellos y las demás resoluciones que expresamente se indi- 
Nuevamente, hay que concretar la eficacia de este criterio en las hipótesis de jurisdicción voluntaria reguladas en las legislaciones autonómicas.

Hay supuestos en los que el legislador autonómico encomienda al juez una función de decisión que puede considerarse de jurisdicción voluntaria y que en la LJV se atribuye al letrado de la Administración de Justicia. De acuerdo con lo dispuesto en el primer apartado de la disposición adicional primera de la LJV, las referencias contenidas en leyes anteriores al juez en relación con asuntos de jurisdicción voluntaria se entenderán hechas al letrado de la Administración de Justicia o al juez con arreglo a lo dispuesto en el art. 2.3 de la LJV.

Es exigible que el legislador autonómico atienda a los criterios del art. 2.3 de la LJV a la hora de establecer la competencia del juez o del letrado de la Administración de Justicia. En la medida en que la atribución de la función a un órgano u otro no es determinante de la configuración del derecho material, tampoco lo es de la competencia de la comunidad autónoma sobre su propio derecho. La solución, por otra parte, contribuye a la coherencia con el diseño estatal de las funciones que corresponden a estos cuerpos estatales (art. 149.1.5 a de la Constitución).

Muy posiblemente, aun sin modificación, la práctica de los operadores jurídicos conducirá a esta interpretación por entender que la LJV es aplicable en todo el territorio nacional y que, de acuerdo con el criterio sentado en la disposición final vigésima de la Ley, la regla es de derecho procesal, dictada al amparo del art. 149.1.6 de la Constitución. Tanto la invocación de la cláusula $5^{\text {a }}$ como de la $6^{a}$ del art. 149.1 permitirían afirmar que, desde la entrada en vigor de la LJV, sin necesidad de reforma de los derechos autonómicos, las funciones que según la nueva regulación corresponden al letrado de la Administración de Justicia quedaron atribuidas automáticamente a estos funcionarios con independencia del derecho civil aplicable. Por razones de seguridad jurídica, empero, convendría que los legisladores autonómicos revisaran sus leyes, en especial dada la compleja concreción de los conceptos que tiene en cuenta el art. 2.3 de la LJV.

La solución práctica interpretativa señalada es más fácil de aceptar cuando las hipótesis autonómicas de jurisdicción voluntaria tienen su equivalente

quen por esta Ley. Cuando no venga atribuida la competencia expresamente a ninguno de ellos, el juez decidirá los expedientes que afecten al interés público, al estado civil de las personas, los que precisen la tutela de normas sustantivas o puedan deparar actos de disposición, reconocimiento, creación o extinción de derechos subjetivos, así como cuando afecten a los derechos de menores o personas con capacidad modificada judicialmente. El resto de expedientes serán resueltos por el secretario judicial». 
material en el derecho civil estatal, en el Código Civil. Resulta en cambio más complejo pronunciarse acerca de si la competencia debe atribuirse al letrado cuando la norma foral designa al juez y el supuesto no tiene equivalente en el derecho estatal. El problema no es solo que la norma contenida en el art. 2.3 de la LJV, y que recoge los criterios para delimitar el reparto de funciones entre el juez y el letrado de la Administración de Justicia, no es una norma absoluta $^{42}$, sino que, además, la especificación de los criterios que utiliza no es obvia.

En la actualidad, en el derecho vigente, nos encontramos con que las leyes autonómicas únicamente atribuyen la competencia al juez, de forma coherente con una regulación de la jurisdicción voluntaria en la que solo se atribuían funciones a la autoridad judicial. Hay que admitir que en algunos de estos casos, de acuerdo con la nueva regulación de la jurisdicción voluntaria, la competencia corresponde ahora al letrado de la Administración de Justicia por tratarse de decisiones que no afectan «al interés público, al estado civil de las personas, los que precisen la tutela de normas sustantivas o puedan deparar actos de disposición, reconocimiento, creación o extinción de derechos subjetivos, así como cuando afecten a los derechos de menores o personas con capacidad modificada judicialmente». Con todo, valorar en cada caso en qué medida la función requerida queda dentro o fuera de esta lista no resulta siempre evidente ${ }^{43}$.

42 Basta pensar, por ejemplo, que en algunos derechos forales hay funciones relacionadas con menores/incapaces que no se atribuyen al juez, sino alternativamente a órganos familiares (la Junta de Parientes, los Parientes Mayores), y que la propia LJV contraría la regla general que pretende sentar en el art. 2.3 cuando atribuye competencia en materia de separación y divorcio tanto al letrado de la Administración de Justicia como al notario, cuando se trata de situaciones tradicionalmente consideradas como definitorias de estados civiles.

Cuando las decisiones afectan a derechos de menores o incapacitados, la competencia claramente debe seguir siendo judicial, pero lo mismo debe entenderse cuando se trata de provocar la extinción de un derecho (extinción del expectante, art. 280.3 del Código Foral aragonés), o de autorizar actos de disposición (en el fideicomiso, art. 426-40 del Código Civil de Cataluña; en la enajenación y gravamen de los bienes por el fiduciario, Ley 233 de la Compilación de Navarra).

Probablemente debe ser judicial la imposición al viudo de la obligación de confeccionar inventario o prestar fianza (arts. 285 y 286 del Código Foral; o, para el viudo fiduciario, art. 450.3 y 4 del Código Foral), aunque no haya menores o personas con capacidad modificada, en la medida en que se impone una obligación; pero, en cambio, la formación del inventario puede atribuirse al letrado de la Administración de Justicia, al igual que los inventarios previstos en las normas catalana (art. 461-23), navarra (ley 319) o vasca (art. 21 de la Ley de 2015) para el beneficio de separación. 


\section{JURISDICCIÓN VOLUNTARIA Y PLURALIDAD DE DERECHOS CIVILES: PANORAMA LEGISLATIVO Y PERSPECTIVAS DE FUTURO}

En estos momentos no cabe formular conclusiones definitivas acerca de la situación actual y futura previsible de la jurisdicción voluntaria en los derechos civiles forales o especiales, ni tampoco acerca de la relación de estos últimos con la LJV aprobada por el legislador estatal el año 2015. Las decisiones afectan a todo el derecho civil autonómico.

En el ámbito de la jurisdicción voluntaria se invocan, entremezclan y superponen competencias legislativas sobre derecho procesal, derecho civil (con sus diferentes contenidos y competencias), el régimen jurídico de las administraciones públicas, régimen estatutario de sus funcionarios y procedimiento administrativo común, que según el reparto de competencias legislativas diseñado por la Constitución de 1978 corresponden de manera diferente al Estado y a las comunidades autónomas. A ello hay que sumar la falta de unanimidad doctrinal que casi cuarenta años después de la Constitución sigue existiendo acerca de la interpretación del art. 149.1.8 a de la Constitución y del alcance de la competencia de las comunidades autónomas para legislar sobre su propio derecho, y que el Tribunal Constitucional no ha resuelto de manera definitiva en las ocasiones en que se ha llegado a pronunciar.

El panorama legislativo actual es el siguiente. De una parte, la legislación autonómica en materia de derecho civil ha alcanzado un desarrollo extraordinario, de modo que a los supuestos de jurisdicción voluntaria que estaban recogidos en las compilaciones de derecho civil se han sumado después de la

Deben quedar reservados a la autoridad judicial los expedientes que impliquen un conflicto abierto: por ejemplo, para fijar la calidad de los bienes con los que se paga la legítima (art. 451-12 del Código catalán).

La revisión debe hacerse en todos los derechos civiles. En Aragón, por ejemplo, para la constitución judicial de la Junta de Parientes probablemente es competente el secretario (art. 175 del Código Foral): refuerza esta conclusión la alternativa de la propia ley aragonesa de que la Junta se constituya bajo fe notarial, luego no es imprescindible la intervención del juez. La remisión a las normas de la tutela de los arts. 50.2 y 51.2 del Código foral son equivalentes a la que se contiene en el art. 71.2 de la LJV, pero hay un detalle que merece la atención: este último precepto termina atribuyendo la competencia para decidir los expedientes al secretario judicial, yo diría que en todos los casos que cita, incluido por tanto el de autorización o aprobación para algunos actos, en contraste con lo dispuesto en el art. 51.2 del Código Foral, que se refiere a la autorización judicial; también habría que corregir la referencia al juez en los arts. 50 y 51 del Código Foral cuando dicen que el juez fija la fianza y los derechos de posesión de los bienes del representante. 
Constitución otros nuevos: a veces sobre instituciones propias del derecho civil autonómico, pero en ocasiones en el ámbito de instituciones que tienen un equivalente en el derecho civil estatal.

La promulgación de la LJV ha supuesto una desjudicialización en este ámbito, de modo que se encomiendan al letrado de la Administración de Justicia y al notario funciones que venían atribuidas a la autoridad judicial en el derecho anterior. El problema se plantea porque el legislador estatal, que es competente para legislar sobre derecho civil y procesal, sobre ordenación de los instrumentos públicos y sobre bases del procedimiento administrativo, no lo es para modificar las normas de derecho civil foral o especial de las comunidades autónomas, que no solo contienen supuestos de jurisdicción voluntaria, sino que atribuyen la competencia para su tramitación a cuerpos de funcionarios de modo no coincidente con lo dispuesto en la regulación estatal.

Desde este punto de vista, la complejidad específica de las relaciones entre la regulación estatal de la jurisdicción voluntaria y la regulación autonómica de derecho civil procede del hecho de que las normas materiales que requieren la intervención de un funcionario para la plena eficacia de un acto privado o para conferir un título de legitimación inciden en la función y en la actividad de esos funcionarios públicos, pertenecientes a cuerpos nacionales (jueces, letrados de la Administración de Justicia, notarios, registradores).

Es evidente que el carácter nacional de un cuerpo de funcionarios públicos no implica que los mismos estén sujetos únicamente al derecho estatal. Con independencia de los aspectos de ordenación jerárquica y de régimen disciplinario, como recuerda la STC 4/2014, todos están sometidos a la esfera de la ley y al derecho (art. 103.1 de la Constitución), esfera que también comprende la legislación dictada legítimamente por las comunidades autónomas en el marco de su competencia. Las consecuencias disciplinarias que pudieran derivarse del incumplimiento del derecho aplicable por parte de estos funcionarios, cuando hubiera lugar a ello, serán las mismas, con independencia de que la norma sea estatal o autonómica.

En el ámbito de la jurisdicción voluntaria resulta relevante tener presente que algunas de las reformas llevadas a cabo por la LJV, comportan la toma de decisiones políticas en las que han influido factores tan diversos como la atención a exigencias y reivindicaciones de ciertos colectivos profesionales (tanto de los notarios como de los secretarios judiciales) o la consideración de razones de oportunidad y de descarga de trabajo de los tribunales. En consecuencia, ni parece razonable que pueda volver a reproducirse a nivel autonómico el debate ocasionado a nivel nacional durante la larga gestación de la ley, ni sería admisible que pudiera zanjarse de una manera diferente.

Posiblemente con este pensamiento, el legislador estatal en la LJV ordena que las referencias que en la misma se contengan al Código Civil y al derecho 
civil estatal deben entenderse hechas también a las normas de derecho foral o especial, considerando que tal declaración por sí misma es suficiente como para producir efectos en los derechos forales, suponiendo que los casos de jurisdicción voluntaria son los mismos en el derecho estatal y en el autonómico, y dando por supuesto también que los aspectos procedimentales en sentido amplio pueden considerarse o derecho procesal, sujeto a la distribución de competencias que resulta del art. 149.1.6 a de la Constitución, o regulación de los instrumentos públicos, materia sobre la que la competencia del Estado es exclusiva, conforme al art 149.1.8 a de la Constitución.

La LJV no invoca en cambio la competencia exclusiva del Estado sobre la Administración de Justicia (art. 149.1.5 a de la Constitución) ${ }^{44}$. Parece evidente que la complejidad de los títulos competenciales concurrentes en la delimitación de los supuestos y en la atribución a una autoridad o funcionario de una función en materia de jurisdicción voluntaria, impedirían lograr el resultado de la aplicación uniforme de la LJV mediante la genérica invocación de la competencia estatal sobre la Administración de Justicia.

En última instancia, si llegara a plantearse una cuestión de inconstitucionalidad de la ley, la capacidad de decisión corresponde al Tribunal Constitucional, y poco importa a estos efectos las manifestaciones del legislador sobre su propia competencia. Con todo, el mensaje que lanza el legislador mediante las invocaciones de competencias legislativas desempeña también un papel pedagógico en la actuación de los juristas llamados a aplicar la ley. De hecho, en la práctica de los operadores jurídicos cabe esperar que se vaya imponiendo la aplicación de la LJV, con toda probabilidad, más que por sólidas razones teóricas, por pragmatismo y comodidad. Al mismo tiempo, no hay que descartar que los legisladores autonómicos se sientan impulsados a desplegar una

44 En la jurisprudencia del Tribunal Constitucional la invocación de esta competencia ha permitido declarar la inconstitucionalidad de normas autonómicas que introducían arbitrajes, considerados como equivalentes jurisdiccionales. Por ejemplo, la STC 18/2011, de 3 de marzo, declara: «En definitiva, el art. 13 b) de la Ley del sector eléctrico canario ha de ser declarado inconstitucional y nulo por cuanto no establece un instrumento de autocomposición extrajudicial como la conciliación o la composición (en cuyo caso no merecería objeción alguna en su confrontación con el art. 149.1.5 a y $6^{a}$ de la Constitución, como se advierte en la STC 31/2010, de 28 de junio, FJ $54)$, sino que articula un procedimiento de arbitraje, que comporta un 'equivalente jurisdiccional', cuyo establecimiento queda reservado a la competencia exclusiva del Estado en materia de legislación procesal civil (art. 149.1.6 y $8^{\mathrm{a}}$ de la Constitución), relacionada, en cuanto a los efectos del laudo arbitral y al sistema de recursos, con la competencia estatal en materia de Administración de Justicia (art. 149.1.5 a de la Constitución)». Con anterioridad, STC 15/1989, de 26 de enero. 
iniciativa legislativa como reacción a una ley estatal que en muchos aspectos contiene una regulación con la que los derechos autonómicos no es compatible. Me parece necesario por ello señalar algunos de los criterios que, en mi opinión, deberían tenerse en cuenta para valorar la competencia para legislar sobre la jurisdicción voluntaria:

a) las comunidades autónomas pueden mantener e introducir supuestos nuevos de jurisdicción voluntaria. Esto es perfectamente posible tanto en el ámbito de instituciones propias como en el ámbito de instituciones que tienen equivalente en el derecho civil estatal. Cuando no existe conflicto abierto, hay que calificar como derecho civil a las normas que exigen la previa autorización para el otorgamiento de actos o negocios, como presupuesto de validez o de oponibilidad y eficacia frente a terceros; también a las normas que, mediante la intervención de un funcionario, se dirigen a facilitar la celebración de actos para el normal desenvolvimiento de relaciones y ejercicio de derechos en situaciones de hecho cuya acreditación rigurosa y formal puede ser suplida por mecanismos más ágiles si concurren determinadas circunstancias de apariencia y notoriedad; igualmente, a las que exigen el cumplimiento de ciertas garantías de forma previa al ejercicio de un cargo o el disfrute de derechos (vgr. confección de inventarios).

Cuando una norma fija presupuestos de validez y eficacia de actos y negocios jurídicos, su naturaleza es material. En consecuencia, corresponde dictarla al legislador con competencia sobre derecho civil, bien sea el legislador estatal, bien el autonómico cuando se trate de derecho civil foral o especial. La delimitación de las hipótesis y los efectos que se vinculan a la tramitación del expediente corresponde también al derecho material, con independencia de que se aplique el procedimiento previsto en la $\mathrm{LJV}^{45}$.

En primer lugar, la consecuencia que se deriva de la afirmación anterior, por lo que se refiere a los supuestos, es la de que cuando la comunidad autónoma regula una materia en el ámbito de su competencia, si no contempla un caso de jurisdicción voluntaria, no se aplica el derecho estatal

45 Así, por ejemplo, los supuestos concretos en los que se exige autorización judicial para el reconocimiento de la filiación no matrimonial es diferente en los arts. 124 y 125 del Código Civil (que son los preceptos que ha tenido en cuenta el art. 23.3 de la LJV) y 235-12 del Código Civil de Cataluña. Pero, como establece el art. 23.1 de la LJV, el procedimiento que se regula en esta Ley se sigue siempre que, según la ley aplicable, sea precisa la autorización judicial. 
que sí lo prevé. Dicho de otra manera más expresiva: no hay aplicación supletoria de supuestos de jurisdicción voluntaria. En segundo lugar, por lo que se refiere a los efectos anudados a la tramitación de un expediente de jurisdicción voluntaria, hay que convenir que son también los que en cada caso establezca el legislador competente, estatal o autonómico, porque el reconocimiento de la eficacia y validez del acto forma parte del Derecho civil material.

b) Los procedimientos previstos en la LJV se aplican cuando el supuesto previsto en la norma autonómica coincide genéricamente con la categoría descrita en la ley estatal ${ }^{46}$, aunque aquella no diga que debe tramitarse como jurisdicción voluntaria. Igualmente cuando una norma autonómica requiere una autorización o una aprobación judicial, en hipótesis que no están contempladas expresamente en la LJV, y con independencia de que el legislador autonómico se remita o no a la misma ${ }^{47}$. En tales casos, la ausencia de un procedimiento expreso para el supuesto contemplado en la norma autonómica se debe solventar recurriendo a las reglas generales de los arts. 13 a 22 de la LJV e integrando lo necesario por aplicación supletoria de la Ley de Enjuiciamiento Civil (así lo requiere el art. 8 de la LJV): por ejemplo, a efectos de fijar la competencia territorial (arts. 2 de la LJV y 52.4 de la Ley de Enjuiciamiento Civil).

Asimismo es aplicable la LJV cuando el derecho autonómico prevé un llamamiento al juez en casos en los que existe un conflicto que, a falta de regulación de un procedimiento de jurisdicción voluntaria podría entenderse que debía tramitarse en un procedimiento contencioso, pero que la ley estatal califica como de jurisdicción voluntaria y para el que prevé un procedimiento de tramitación ${ }^{48}$. En algunos casos, incluso, por analogía con otros supuestos previstos en la legislación estatal ${ }^{49}$.

46 Por ejemplo, autorización judicial para el reconocimiento de la filiación, para la aceptación de la herencia, nombramiento de defensor judicial, etc. Aunque los supuestos concretos vengan determinados por el derecho civil aplicable de forma no idéntica. Por ejemplo, para los casos de intervención del juez en caso de asistencia cuando se trata de un menor mayor de catorce años (arts. 23 y ss. del Código Foral de Aragón). Por ejemplo, el art. 187 del Código Foral establece los criterios para fijar la contribución a las cargas familiares en defecto de acuerdo de los cónyuges; si no se ponen de acuerdo, hay un conflicto: en principio, debería ventilarse en un juicio contradictorio; sin embargo, el art. 90 de la LJV regula para este supuesto un procedimiento de jurisdicción voluntaria; el Código Foral prevé el supuesto, y no hay especialidad aragonesa para establecer un régimen diferente (art. 149.1.6 de la Constitución).

49 Así, la resolución de divergencias que surjan acerca de la titularidad de la autoridad familiar por personas distintas de los progenitores, de forma alternativa a la decisión 
También es aplicable la LJV cuando, atribuida la competencia al mismo órgano en la norma autonómica y en el Derecho estatal, la LJV introduce una norma de puro procedimiento que no se encuentra en la norma autonómica ${ }^{50}$.

En todos estos casos, la tramitación en sede de la administración de justicia está sujeta a las reglas procedimentales establecidas en la ley estatal.

c) En los distintos supuestos considerados como jurisdicción voluntaria se atribuye una función a funcionarios de cuerpos únicos nacionales (jueces y magistrados, letrados de la Administración de Justicia, notarios). Resulta indeseable contar con soluciones diferentes para los mismos supuestos en función del derecho civil aplicable, pero es compleja la cuestión de la competencia constitucional para legislar sobre estas materias.

Cuando se trata de atribuir una función a un órgano de la Administración de Justicia (juez o letrado de la Administración de Justicia) el legislador autonómico debe tener en cuenta los criterios de distribución de funciones que resultan del art. 2.3 de la LJV, que en la medida en que señala las funciones de los órganos de la Administración de Justicia, puede considerarse comprendido en el $149.1 .5^{\text {a }}$ de la Constitución (competencia exclusiva del Estado). Y aunque se considerara procesal, que es lo que resulta de la disposición final vigésima de la LJV, la solución no afecta al derecho material ni hay razones de especialidad del derecho autonómico que justifiquen la adopción de un criterio diferente.

d) El legislador autonómico, al prever un supuesto de jurisdicción voluntaria puede, además de delimitar su ámbito y establecer los efectos del expediente, encomendar esa función a órganos de carácter familiar consuetudinario. En aquellos sistemas cuya tradición, recogida en el derecho vigente al aprobarse la Constitución, contaba con órganos familiares (la

de la Junta de Parientes (art. 89 del Código Foral), y de forma análoga a los casos de discrepancias sobre el ejercicio de la función. O, por ejemplo, hay un supuesto semejante a los de desacuerdos entre los cónyuges sobre la administración, pero propio del derecho aragonés, y no contemplado en la LJV: el del art. 280.3 del Código Foral, para el que el auto de la AP de Zaragoza de 27 de marzo de 2007, admitió la tramitación en expediente de jurisdicción voluntaria, considerando suficiente que el cónyuge fuera emplazado, no compareciendo ni manifestando oposición (lo que hubiera transformado en ese momento el procedimiento en contencioso).

Así, el art. 37 de la LJV regula el asentimiento a la adopción ante el juez, pero añade que no es necesario si se ha prestado dentro de los seis meses anteriores en escritura pública o ante la entidad pública. Ni la legislación estatal contenida en el Código Civil ni el Código Civil de Cataluña contienen esta previsión, pero puede considerarse una norma de puro procedimiento aplicable también en el derecho autonómico. 
Junta de Parientes, los Parientes Mayores), resulta más sencillo admitir la constitucionalidad de las normas autonómicas que, al ejercer legítimamente su competencia sobre su propio derecho civil, les confieren nuevas intervenciones. El problema es más bien, y hay que señalarlo, la amplitud con la que se está interpretando la competencia autonómica en virtud de la doctrina de las instituciones conexas a que se refirió la STC 156/1993, lo que ha dado lugar a que la legislación autonómica se esté legitimando por la vía de hecho en todos los ámbitos que no se encuentran reservados

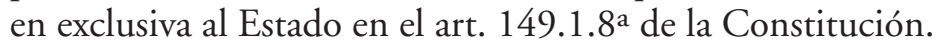

La atribución de funciones a órganos familiares, en especial relacionadas con menores y personas con discapacidad, no supone vulneración de sus derechos siempre que no se excluya el control judicial. La cuestión es otra: la falta de certeza en torno al alcance de las competencias de las comunidades autónomas sobre su propio derecho civil impide responder de manera segura acerca de lo que diría el Tribunal Constitucional en el caso de que tuviera que resolver sobre si las comunidades que carecen de una tradición de órganos familiares recogida en su derecho vigente en el momento de entrar en vigor la Constitución pueden importar y desarrollar figuras semejantes en aras de simplificar el funcionamiento de algunas instituciones y de la desjudicialización de algunas esferas judiciales (por ejemplo, para autorizar actos de administración y disposición de representantes legales o guardadores de menores y personas con discapacidad).

e) Es indudable que la posibilidad de acudir a los tribunales en caso de conflicto entre los particulares queda sujeta a los cauces de la legislación procesal, materia de competencia exclusiva del Estado. Resulta discutible que un legislador autonómico tenga competencia para ordenar que ciertos supuestos de su derecho civil propio, en los que se ha suscitado una discrepancia entre las partes, se tramiten como expedientes de jurisdicción voluntaria. En tales casos no puede identificarse una norma de derecho material: por el contrario, la remisión a la jurisdicción voluntaria es una opción procedimental y, entonces, en principio, habría que concluir que la competencia para establecerla viene determinada por lo dispuesto en el art. 149.1.6a de la Constitución. El problema es que, como ha quedado apuntado más arriba, la jurisprudencia constitucional no permite anticipar con seguridad los criterios que justificarían una regulación procesal autonómica ex art. 149.1.6a de la Constitución.

Cuando se trata de una institución propia del derecho civil especial, resulta más fácil aceptar que la competencia del legislador autonómico para valorar la oportunidad de una remisión a la jurisdicción voluntaria como cauce para la resolución de conflictos menores está estrechamente vinculada con 
el propio ámbito material del derecho en el que se inserta. Es la apreciación de la urgencia de la solución requerida por el interés que se ventila, o la sencillez del problema planteado lo que moverá a prever la tramitación del expediente como jurisdicción voluntaria. En el ámbito del derecho civil especial no se ve inconveniente en admitir esta opción legislativa siempre que no se vulnere el derecho a la tutela judicial del art. 24 de la Constitución, lo que implica que no se puede excluir la acción judicial.

Con todo, el asunto adquiere rasgos específicos en el momento en que, en virtud de la norma autonómica, se produce el sometimiento de conflictos a órganos no judiciales. Este es el caso de la Junta de Parientes de Aragón o de los Parientes Mayores de Navarra, a los que me he referido ya.

A la intervención de este órgano "familiar» se someten voluntariamente los particulares, como alternativa a la decisión judicial en los casos en los que la ley requiere su intervención ${ }^{51}$. A la ley autonómica le está vetado crear tribunales, ni siquiera tribunales familiares, para lo que se requeriría una ley orgánica (art. 122 de la Constitución), por lo que las decisiones de la Junta o de los Parientes no pueden tener el valor de una sentencia, ni siquiera cuando resuelven una controversia ${ }^{52}$, y su valor es meramente contractual $^{53}$. La conclusión que se impone, por tanto, es la de que cuando la norma foral requiere la intervención de un órgano "privado», no estatal, para resolver un conflicto familiar o sucesorio en los términos señalados, estamos dentro de la competencia sobre el derecho civil propio.

f) Nada impide que el legislador autonómico encomiende al notario una función, siempre que se mantenga entre las que le son propias, conforme a su normativa reguladora y que no invada las de otros funcionarios (en particular, la jurisdiccional de juzgar y hacer ejecutar lo juzgado, que corresponde en exclusiva a jueces y magistrados). Ello no constituye una intromisión en la competencia que corresponde en exclusiva al Estado sobre la ordenación de los instrumentos públicos porque, como advirtió el Tribunal Constitucional, no es «aceptable un entendimiento tan lato de esta competencia estatal que venga a impedir toda ordenación autonómica sobre actos o negocios jurídicos con el solo argumento de

51 Así, desacuerdos en el ejercicio de la patria potestad (ley 69 de la Compilación navarra), conflictos sobre la titularidad de la autoridad familiar de personas distintas de los padres (art. 89 del Código Foral aragonés), o discrepancias entre los cónyuges para fijar el domicilio familiar (art. 184 del Código Foral).

52 Nada impide que en un proceso ordinario puedan las partes interesadas o el juez, según las circunstancias, analizar el tema de que se trate en cuanto al fondo.

53 Así, expresamente, art. 178.3 del Código Foral aragonés. 
que unos $\mathrm{u}$ otros pueden o deben formalizarse mediante instrumento público" (STC 156/1993, de 6 de mayo). El mismo criterio favorable a la competencia autonómica se ha mantenido en otras sentencias posteriores, como ya hemos visto.

Aunque el Tribunal Constitucional no se ha pronunciado sobre la jurisdicción voluntaria, de su doctrina se desprende que, en el equilibrio que debe establecerse entre la competencia exclusiva del Estado para la ordenación de los instrumentos públicos y la que corresponde al legislador autonómico sobre su derecho civil foral o especial, a este último hay que reconocerle la posibilidad de prever, para las materias que estén dentro de su ámbito de competencia, el otorgamiento de escrituras públicas en las que se recojan actos y negocios inscribibles, que produzcan efectos frente a terceros, así como de actas de notoriedad que recojan hechos y juicios del notario a los que se atribuyan efectos.

g) El problema se plantea de manera específica tras la LJV, en las hipótesis en las que la norma autonómica atribuye la competencia al juez, de forma alternativa o exclusiva con el notario, mientras que la legislación estatal se la atribuye solo a este último. Sirve aquí de ejemplo paradigmático la interpelación al llamado a una herencia (también la repudiación a la misma).

Si se acepta que es legislación civil todo el contenido de los arts. 1005 y 1008 del Código Civil, ninguna influencia tendría su modificación en el derecho civil foral o especial: en Cataluña y en Aragón la interpelación seguiría siendo judicial y la repudiación de la herencia podría hacerse tanto en escritura pública como mediante escrito dirigido al juez competente.

Pero hay que convenir en que si se sostiene que los arts. 348 y 351 del Código Foral de Aragón y 461-6 y 461-12 del Código Civil de Cataluña mantienen su vigencia mientras no los reforme el legislador autonómico, y que la nueva redacción de los arts. 1005 y 1008 del Código Civil es una «simple» modificación del derecho civil ${ }^{54}$, la conclusión sería muy poco satisfactoria desde el punto de vista práctico ${ }^{55}$.

54 No sería un argumento definitivo (de hecho la disposición final vigésima de la LJV, sobre título competencial, contiene errores evidentes, como considerar que la modificación de la ley sobre títulos nobiliarios es mercantil), pero el legislador estatal justifica la modificación de los arts. 1005 y 1008 del Código Civil, llevada a cabo por la disposición final primera de la LJV, en la «competencia que corresponde al Estado en materia de legislación civil conforme al art. 149.1.8 a de la Constitución».

55 En efecto, habría que negar eficacia en el ámbito de aplicación de estos derechos a una interpelación notarial, porque la ley autonómica no la contempla: no cabría 
Cabe, sin embargo, proponer una argumentación teórica alternativa. Si se admitiera que las normas autonómicas se limitaban en estos supuestos a reiterar la regulación estatal sin pretensiones de introducir un régimen propio, con la sola finalidad de dotar de sentido e inteligibilidad a su texto normativo (cfr. el argumento en la STC 201/2013, de 5 de diciembre), por no existir especialidad sustantiva, podría considerarse que la supresión de la competencia judicial en la norma estatal habría supuesto la desaparición de la norma procesal de la que la autonómica era una mera repetición. En consecuencia, habría desaparecido el apoyo de la norma autonómica, cuya constitucionalidad podría defenderse por la consideración de que la reproducción de la norma estatal se realizaba con la única finalidad de dotar de sentido al texto normativo. Así las cosas, la norma autonómica debería integrarse por la nueva norma estatal: no porque deba calificarse de procesal — como ya he explicado más arriba, no puede serlo la norma que atribuye competencia al notario-, ni porque suponga una ordenación de los instrumentos públicos, sino por su condición de derecho supletorio, en virtud de lo dispuesto en el art. 149.3 de la Constitución.

Lege ferenda, por lo que se refiere a la posibilidad de que las comunidades autónomas mantengan también la interpelación judicial, hay que recordar que esta es la solución actual del derecho navarro, donde la ley 315 de la Compilación de Navarra contempla el «requerimiento judicial o

aplicación supletoria del art. 1005 del Código Civil, porque existe regulación propia, y la competencia no está atribuida al notario ni en la LJV ni en la Ley del Notariado, por lo que no cabe argumentar con la aplicación directa de estas leyes. La solución no parece adecuada, por las ventajas de agilidad para el ciudadano y descarga de los tribunales que ofrece la interpelación notarial, por lo que para zanjar el problema sería preferible que se introdujeran expresamente en las leyes autonómicas.

Por otra parte, lege data, los jueces deberían seguir declarándose competentes para hacer el apercibimiento si se les solicita conforme al art. 348 del Código Foral de Aragón o art. 461-12 del Código Civil de Cataluña, o si se les dirige un escrito de repudiación de la herencia conforme a los arts. 351 del Código Foral de Aragón y 461-6 del Código Civil de Cataluña. En la práctica, sin embargo, como hemos visto, no ha sido raro que los jueces se declaren incompetentes para conocer de las solicitudes que se les presentan (art. 48 de la LJV, apreciación de oficio de la falta de competencia objetiva), por entender que se les ha privado de tal competencia en estos expedientes por la LJV (en este sentido, el ya citado Auto 437/2015 del JPI no 27 de Barcelona, de 10 de diciembre de 2015). 
extrajudicial». A favor de mantener la competencia judicial juega que ${ }^{56}$, si se atribuye a los notarios en exclusividad, este expediente no es de los que se incluyen en la disposición final decimonovena de la LJV acerca de la gratuidad prevista para la asistencia jurídica gratuita (en materia de sucesiones se incluyen solo los expedientes de declaración de herederos abintestato; el de presentación, adveración, apertura y lectura, y protocolización de testamentos, y el de formación de inventario) ${ }^{57}$. No es discutible, sin embargo, que en contra de mantener la competencia de los jueces en estos expedientes juega claramente la contradicción con la decisión del legislador estatal, que ha excluido la competencia judicial en unas materias sobre las que no existe especialidad autonómica.

h) La falta de seguridad en la determinación de las relaciones entre el derecho civil autonómico y la regulación estatal de la jurisdicción voluntaria no constituye un problema específico de esta normativa, sino que es el reflejo de la incertidumbre existente acerca del alcance de las competencias de las comunidades autónomas sobre el derecho civil foral o especial propio.

Casi cuarenta años después de la Constitución, el Tribunal Constitucional no ha sentado criterios claros ni la doctrina jurisprudencial dictada hasta ahora permite anticipar cuál sería el resultado previsible de una resolución en la que se planteara el problema. La oscuridad del art. 149.1.8 de la Constitución y las discrepancias doctrinales y políticas son parte de la explicación. La dificultad para calificar la naturaleza de los actos de jurisdicción voluntaria y la complejidad del sistema de distribución de competencias normativas entre el Estado y las comunidades autónomas, tanto en el terreno sustantivo como procesal, contribuyen a esta inseguridad. Indudablemente, es este un ámbito en el que las huidas hacia delante, tanto por el legislador estatal como por los autonómicos, requieren un debate serio y profundo del modelo de derecho civil español que se quiere, y la toma de decisiones a nivel nacional que, si es necesario, lleve a una reforma de la Constitución.

56 El mismo argumento serviría para la repudiación: aunque es verdad que el componente de documentación — típica función notarial— es relevante, quizás no sea decisivo, por las consecuencias de tal declaración.

57 A pesar de que, en el último párrafo del apartado VIII de la exposición de motivos de la LJV se afirma que: «En la medida que la presente Ley de la Jurisdicción Voluntaria desjudicializa y encomienda a notarios y registradores de la propiedad y mercantiles determinados expedientes en exclusividad, se prevé que los ciudadanos que tengan que acudir a los mismos puedan obtener el derecho de justicia gratuita, para evitar situaciones de imposibilidad de ejercicio de un derecho, que hasta ahora era gratuito, por falta de medios». 


\section{BIBLIOGRAFÍA}

Alonso Furelos, J. M. (2015). La jurisdicción voluntaria ante su reforma: opciones. Revista de Derecho de la UNED, 16, 19-63.

Banacloche Palao, J. (2015). Los nuevos expedientes y procedimientos de Jurisdicción Voluntaria. Análisis de la Ley 15/2015, de 2 de julio, La Ley. Disponible en: http://www. smarteca.es/LinkToSmarteca?publication=SMT2015087_00000000_0 2015.

Bercovitz Rodríguez-Cano, R. (1993). La conservación, modificación y desarrollo por las Comunidades Autónomas de los derechos civiles, forales o especiales. Derecho Privado y Constitución, 1, 15-82.

- (2014). El galimatías competencial. Revista Doctrinal Aranzadi Civil-Mercantil, 1, parte Tribuna, 1-3.

Busto Lago, J. M. (1999). Competencias legislativas de las Comunidades Autónomas sobre las «necesarias especialidades» procesales que se deriven de su Derecho substantivo propio (comentario a la STC 127/1999, de 1 de julio). Derecho Privado y Constitución, 13, 81-116.

- (2004). Ámbito de la competencia de los Tribunales Superiores de Justicia en materia de Derecho civil: especialidades en la regulación autonómica del recurso de casación en materia de Derecho civil propio de Galicia (A propósito de la STC 47/2004, de 25 de marzo). Derecho Privado y Constitución, 18, 89-142.

Caballol i Angelats, Ll. (2012), Consideraciones en torno a la constitucionalidad del art. 43 del Código de Familia de Cataluña con motivo de la sentencia del Tribunal Constitucional 21/2012, de 26 de febrero. InDret: Revista para el Análisis del Derecho, 3, 1-24.

Cabanas Trejo, R. y Ballester Azpitarte, L. (2015). Ley 15/2015, de 2 de julio, de la Jurisdicción Voluntaria», parte III. Boletín Jurídico Mensual [blog], 14-7-2015. Disponible en: https://boletinjuridico.wordpress.com/2015/07/14/ley-152015-de-2de-julio-de-la-jurisdiccion-voluntaria-parte-iii/.

Consejo General del Poder Judicial (2014). Informe al anteproyecto de ley de la jurisdicción voluntaria, aprobado por el Pleno el 27 de febrero de 2014. Disponible en: http:// www.poderjudicial.es/cgpj/es/Poder_Judicial/Consejo_General_del_Poder_Judicial/Actividad_del_CGPJ/Informes/Informe_al_Anteproyecto_de_Ley_de_Jurisdiccion_voluntaria.

Espiñeira Soto, I. (2016). Acta de interpelación del art. 1005 del Código Civil. Disponible en: http://www.notariosyregistradores.com/web/secciones/oficina-notarial/ modelos/acta-de-interpelacion-del-articulo-1005-del-codigo-civil/.

Feás Castilla, J. (2016). Aceptación y repudiación de la herencia. En P. Barrio del Olmo (coord.). Jurisdicción Voluntaria Notarial. Estudio Práctico de los nuevos expedientes en la Ley de la Jurisdicción Voluntaria, Ley Hipotecaria y Ley de Navegación Maritima (pp. 807-848). Pamplona: Aranzadi.

Gomá Lazón, I. (2016). Nuevas atribuciones y función notarial. En P. Barrio del Olmo (coord.). Jurisdicción Voluntaria Notarial. Estudio Práctico de los nuevos expedientes 
en la Ley de la Jurisdicción Voluntaria, Ley Hipotecaria y Ley de Navegación Maritima (pp. 41-51). Pamplona: Aranzadi.

González Poveda, B. (1997). La jurisdicción voluntaria, Doctrina y Formularios, $3^{\mathrm{a}}$ ed. Pamplona: Aranzadi.

Malaurie, P., Aynès, L. y Brenner, C. (2014). Les successions. Les liberalités, 6a éd. Issy-les-Moulineaux: Lextenso éditions, LGDJ.

Marín López, J. J. (1994). La ordenación de los Registros e instrumentos públicos como título competencial del Estado. Derecho Privado y Constitución, 2, 111-195.

Melero Bosch, L. V. y Reverón Palenzuela, B. (2006). La competencia de las comunidades autónomas para legislar en materia de recurso de casación civil. Comentario a la sentencia del Tribunal Constitucional 47/2004, de 25 de mayo. Anales de la Facultad de Derecho, 23, 173-186.

Parra Lucán, M. A. (2016, en prensa). Comentario a los apartados 5-8 de la Disposición final octava. En A. Fernández de Buján y A. Serrano de Nicolás (dirs.). Comentarios a la Ley de la Jurisdicción Voluntaria. Pamplona: Civitas.

Pérez de Ontiveros Baquero, C. (2014). Competencia de las Comunidades Autónomas sobre el régimen del recurso frente a la calificación negativa de los registradores. Algunas reflexiones tras la STC 4/2014, de 14 de enero. Derecho Privado y Constitución, 28, 11-46.

Prados Ramos, L. (2015). La interpellatio in iure en Catalunya. Luis Prados Ramos Notario [blog], 18-10-2015. Disponible en: http:/www.notarialuisprados.com/la-interpellatio-in-iure-en-catalunya-puede-hacerse-ante-notario/. 
